Lang. Soc. 15, 313-348. Printed in the United States of America

\title{
Linguistic constraints on intrasentential code-switching: A study of Spanish/Hebrew bilingualism*
}

\author{
SUSAN BERK-SELIGSON \\ Department of Hispanic Languages and Literatures \\ University of Pittsburgh
}

\begin{abstract}
In recent years, research has increasingly pointed toward the universality of three linguistic constraints on code-switching: (I) an equivalence of structure constraint, (2) a size-of-constituent constraint, and (3) a free morpheme constraint. The evidence derived from this study challenges the universality of the first two of these constraints, and argues instead that their claim to universality is largely a function of the coincidental relative similarity in the syntactic structure of Spanish and English, the two languages upon which most code-switching studies have been based. The present study breaks out of the Spanish-English mold and draws upon data from a language contact situation in which the two languages are syntactically very different from each othici, namely, Spanish and Hebrew. The evidence presented also challenges the frequently made assertion that type of code-switching, namely, intra- versus intersentential code-switching, is correlated with degree of bilingualism of the speaker. Finally, the evidence suggests that intrasentential code-switching ability cannot, as some have argued, universally be considered a measure of bilingualism nor a mark of the balanced bilingual. (Code-switching, Spanish, Hebrew, bilingualism, syntactic constraints)
\end{abstract}

\section{THEORETICAL FRAMEWORK}

Studies on code-switching have blossomed in recent years, the bulk of them concentrating on social and functional factors that operate to constrain it (Genishi 198I; Gumperz 1971, 1976; Gumperz \& Hernández-Chávez 1975; HuertaMarcías I98I; McClure I98I; Valdés-Fallis I976, I98I). ${ }^{1}$ However, a growing number of code-switching studies have dealt with the linguistic factors that come into play (Gingrás 1974; Gumperz 1976; Pfaff 1976, I979; Poplack 1980, I98 I; Timm 1975; Wentz 1977; Zentella 198I). From these studies, three general linguistic constraints have emerged. They have been explained as follows.

The equivalence of structure constraint, or "equivalence constraint," as Poplack (1980) has called it, can be stated most simply in this way: "Surface structures common to both languages are favored for switches"' (Pfaff I 979:3I4).

0047-4045/86/ I 50313-36 \$2.50 C) 1986 Cambridge University Press 
Poplack (1980:586) has been the most comprehensive in elaborating on the constraint:

Code-switches will tend to occur at points in discourse where juxtaposition of $\mathrm{L}_{1}$ and $\mathrm{L}_{2}$ elements does not violate a syntactic rule of either language, i.e., at points around which the surface structures of the two languages map onto each other. According to this simple constraint, a switch is inhibited from occurring within a constitutent generated by a rule from one language which is not shared by the other.

Lipski (1978:258) specifies the equivalence constraint even further: "Whereas, the portion of the code-switched utterance that falls before the codeswitch may indeed contain syntactically divergent elements, those portions falling after the switch must be essentially identical syntactically."

The size-of-constituent constraint says that higher-level constituents, that is major constituents (e.g., sentences, clauses) tend to be switched more frequently than lower-level constituents, or smaller ones (i.e., one-word categories such as nouns, determiners, verbs, adverbs, adjectives) (Gumperz \& Hernández-Chávez 1975; Poplack 1980). This constraint, in turn, derives from the more generà! constraint which says that codeswitches occur primarily at phrase structure boundaries (Hasselmo 1970; Poplack 1980; Shaffer 1978). The one regularly found exception to the size-of-constituent constraint is the category noun. Below the level of the sentence, nouns consistently have been found to comprise the greatest number of switches (Pfaff 1979; Poplack 1980, 1981; Timm 1975; Wentz I 977).

The size-of-constitutent constraint has important ramifications for theories of bilingualism, in that size of constituent repeatedly has been found to be correlated with the bilingual ability of the speaker. Studies of child bilingual language acquisition (McClure I98I; Zentella I98I) and adult bilingualism (Pfaff I979; Poplack I98I) consistently have shown that frequent intrasentential code-switching is associated with high bilingual ability, whereas use of intersentential switching is associated with nonfluency or dominance in one language over the other. These findings, in turn, have led some scholars (Poplack I980, I98I) to the conclusion that the ability to code-switch intrasententially may be used as a measure of bilingual competence.

The third linguistic constraint on code-switching, the free morpheme constraint, has been confirmed by a number of studies (McClure 198I; Pfaff I979; Poplack 1980, 198I; Wentz 1977). It states, in short, that code-switching is prohibited between a free and a bound morpheme, or in Poplack's (1980:58586) terms, "Codes may be switched after any constitutent in discourse provided that constituent is not a bound morpheme." This would mean, for example, that an item such as *EAT-iendo 'eating', which consists of a Spanish bound morpheme -iendo '-ing' affixed onto an English root, 'eat', could not occur in the speech of a Spanish/English bilingual, and has never been attested, "unless one 
of the morphemes has been integrated phonologically into the language of the other" (Poplack 1980:586), that is, unless the word had attained the status of a borrowing. Wentz and McClure (n.d.:245) have characterized this constraint somewhat more narrowly in their statement that, "no words with morphology from both languages can exist without first having the stem integrated into the language of the suffix phonologically and semantically." Poplack (1980:586, 1981:175) extends the jurisdiction of the free morpheme constraint to cover idiomatic expressions and frozen forms (e.g., "cross my fingers and hope to die," "'si Dios quiere y la virgen"' [God and the virgin willing]). In actuality, all of these definitions are somewhat too narrow, in that they allow for the possibility of switching between a bound and a free morpheme (e.g., between a prefix and a stem). Thus, the free morpheme constraint would best be defined as the impossibility of code-switching at a point of morpheme binding.

The acceptance of the above three constraints has led Poplack (1980:6 I5) to the conclusion that, "code-switching is itself a discrete mode of speaking, possibly emanating from a single code-switching grammar composed of the overlapping sectors of the grammars of $\mathrm{L}_{1}$ and $\mathrm{L}_{2} \ldots$. ," and that "the outer areas where there is no equivalence will tend to be reserved for monolingual segments of discourse" (Poplack I981:183). Her most convincing evidence for this hypothesis is the fact that for the twenty speakers in her study, "there are virtually no ungrammatical combinations of $L_{1}$ and $L_{2}$ in the $I, 835$ switches studied, regardless of the bilingual ability of the speaker" (Poplack 1980:613). Additional support for her hypothesis that code-switching is not monolithic behavior is the fact that nonfluent bilinguals can code-switch frequently, while preserving grammaticality in both $\mathrm{L}_{1}$ and $\mathrm{L}_{2}$, through the strategy of avoiding intrasentential code-switching in favor of intersentential switching.

It is the purpose of this paper to reexamine the hypothesized universal validity of all three of the linguistic constraints discussed above in the light of codeswitching that is the outcome of two syntactically relatively more divergent languages than are Spanish and English. The data base which is used to do so is derived from the speech of eighty-seven Spanish/Hebrew bilingual informants who generated a total of 3,77 I code-switches. ${ }^{2}$

SPANISH AND HEBREW IN CONTACT: A SOCIOLINGUISTIC HISTORICAL SKETCH

Spanish and Hebrew have been in contact with each other for over a thousand years, albeit up until the nineteenth century that contact had been between a spoken, living language, on the one hand, and a written language, on the other. That dialect of Spanish was the Spanish of Jews who had been living in Spain until I 492, the time of the Inquisition and their subsequent expulsion, and the Spanish of their descendants, who continued to speak it in those lands where they ultimately settled, the Ottoman Empire. In this century, the descendants of those 
Spanish Jews have been living primarily in the nation-states that emerged from that empire, namely, Rumania, Bulgaria, Yugoslavia, Turkey, Greece, Morocco, Egypt, Syria, Israel, and elsewhere as well (e.g., the United States). These descendants are known as "Sephardim" or "Sephardic Jews." The sociolinguistic history of the Sephardim has been described fully in recent studies (Harris 1979; Malinowski 1979).

The Spanish of the Sephardim, to be referred to here as "Judeo-Spanish,"' but known also under the name of "Ladino," is a variety of Spanish characterized essentially by fifteenth-century Spanish phonology and morphology, which give it its "archaic" quality, plus a lexicon very rich in borrowings from the languages with which Judeo-Spanish has been in contact. ${ }^{3}$ These contact languages, as evidenced by the vocabulary borrowed from them, have been Turkish, French, Greek, Italian, Portuguese, Hebrew, Arabic, and several Slavic languages (Harris 1979; Hirsch I95 I; Luria 1930; Malinowski 1979; Wagner 1914). The syntax of Judeo-Spanish, however, is essentially that of Modern Spanish, since the syntax of Old Spanish, that stage of Spanish spoken in the fifteenth and sixteenth centuries, is virtually the same as that of Modern Spanish (Alonso I 962:459; Crews 1935:28; Harris 1979:42-43).

To say that Judeo-Spanish has been in contact with Hebrew for over a thousand years is to say two things. First of all, in the preexpulsion Spanish era, especially the Middle Ages, learned Jews in Spain were writing texts in Hebrew (Harris 1979). Over the centuries of exile in the Ottoman Empire, however, the Sephardim began translating the Bible and other sacred texts into Spanish. Yet the Spanish translations were filled with words of Hebrew-Aramaic origin, many of which had been part of the oral Judeo-Spanish tradition even prior to I 492 (see Bunis 1975; Gold 198I; Harris I979; Hassán 1963). ${ }^{4}$ The oral language of Judeo-Spanish speakers, too, was filled with such Hebrew-Aramaic vocabulary in postexpulsion times. Oral samples of Judeo-Spanish collected in the Balkans in the I930s attest to the presence of this Hebrew-Aramaic component in the speech of both men and women alike (Crews 1954-55). Finally, for those among the Sephardic population who came directly to Palestine after the Spanish Inquisition, settling primarily in the cities of Jerusalem, Safed, Tiberias, and Hebron, Hebrew was present both as a written and as an oral medium, since the learned religious men there continued to write scholarly texts in Hebrew, and to a lesser extent, to speak it. For the ultraorthodox, Hebrew was a holy tongue, to be used exclusively for religious purposes.

Accurate historical information on the extent to which Judeo-Spanish and Hebrew were used in a bilingual context in Ottoman Palestine is difficult to obtain, since even the extent of Hebrew-speaking in and of itself is difficult to pin down until the period 1916-19, the earliest period for which census data on the subject are available. One thing that is clear is that the Sephardim living in Palestine from the time of their expulsion from Spain did not give up their Spanish mother tongue. ${ }^{5}$ As for information on the use of spoken Hebrew in 
Palestine, there is evidence that as early as 1816 , Jews in Jerusalem had been seen conversing entirely in Hebrew (Parfitt 1972:243) ${ }^{6}$ Efforts to revive Hebrew as a spoken lainguage on a mass scale, as part of a nation-building mechanism, did not begin until 1882 , however. ${ }^{7}$ Drawing on census data, Schmelz and Bachi (1974:5) have concluded that at the end of the period of Turkish rule in Palestine (1916-19), 18.3 percent of Sephardic children in the country were speaking Hebrew as their principal language and 8.4 percent of Sephardic parents were doing so. This is surprisingly high, given the fact that Hebrew did not become an official language in Palestine until 1922, the beginning of the period of British Mandate. ${ }^{8}$ And even though the majority of Sephardim at the time were not speaking Hebrew as their principal language, it is known that for at least one hundred years prior to that point, the Sephardim had relied on Hebrew as a lingua franca when speaking to members of the other ethnolinguistic groups in whose proximity they lived, just as the Yiddish-speaking Ashkenazim (that is, Jews of Western and Eastern European descent) and the Arabic-speaking Oriental Jews had (Fellman 1973; Parfitt 1972).

Spanish continued to be used in Palestine throughout the British Mandate as Sephardim continued to emigrate from the Balkans, and received a particularly great impetus in I948, when a number of those European Sephardim who had survived the Holocaust (see Harris [1979] and Malinowski [1979]) began their exodus to the newly formed State of Israel. Finally, Spanish has come into renewed contact with Hebrew as a consequence of the immigration of Latin American Spanish-speaking Jews, predominantly Argentines, in the past fifteen to twenty years. ${ }^{9}$ It is estimated (Malinowski I979:I I I) that there are about 60,000 Latin American-born Jews currently living in Israel. These 60,000 , together with somewhere between 63,000 and I00,000 Judeo-Spanish speakers, comprise some $123,000-160,000$ persons living in Israel today who, to some extent, use Spanish in addition to Hebrew. ${ }^{10}$

\section{THE SAMPLE}

The sociolinguistic setting for the data collection

All of the Judeo-Spanish and Latin American Spanish speakers from whom codeswitching data were collected are residents of Jerusalem. Whereas the Latin Americans tend to be spread out throughout a variety of upper-middle class neighborhoods in the city, forming no concentrations in any one neighborhood, the Judeo-Spanish speakers tend to live together in neighborhoods, mainly poorer, working-class ones, where they make up a sizeable ethnic constituent alongside two other ethnic-linguistic groups: Arabic-speaking Oriental Jewish Israelis (i.e., Jews whose country of origin was the Middle East) and Yiddishspeaking ultra-orthodox Ashkenazim. ${ }^{11}$ The linguistic fieldwork was carried out predominantly in one such neighborhood, considered by local residents actually 
to comprise two contiguous neighborhoods, Maskéret Mosé and Ohél Mošé, an area bordering on West Jerusalem's largest open-air market, the Maxané Yehudá. ${ }^{2}$ The neighborhood is among the earliest to be populated outside the walls of the Old City, and in fact, most of the native-born older persons included in the sample have been living in their current houses for over fifty years, their childhood and teenage years having been spent within the walls of the Old City. Built entirely of stone, often with their original stone floors, these houses only in the past twenty years have been equipped with indoor plumbing and running water.

Much of the fieldwork was conducted in the community recreation center (or moadón) of Maskéret Mošé. There, every weekday morning, somewhere between twenty and forty middle-aged and elderly women, ranging from the age of forty-five to ninety come to participate in a government-run program designed especially for the elderly. The activities are organized by a social worker, who schedules a regular routine of calisthenics, guest lectures, celebrations of national holidays, outings to places of interest, and service activities such as volunteer work in hospitals and military posts. All of the women who attend the moadón are ethnically Sephardic or Oriental, the Sephardim making up by far the majority (about 75 percent) of the group. The moadón is a particularly good place for gathering natural linguistic data, in that women begin arriving for the sessions up to an hour before they are to begin, and spend that time chatting and gossiping. In fact, these highly informal styles continue throughout the entire meeting, as most women use the moadón session primarily as an outlet for social activity. My presence at these meetings, once accounted for, became unobtrusive, thereby allowing me to tape-record highly informal, lively verbal interchanges, without having to be included in the conversations myself.

Another setting that was used for recording natural conversation was the street. Often I would leave the moadón in the company of one or more women, and would walk with them to their doorstep. This, in turn, often led to an invitation to enter the house, and so the progression of conversation often continued in the home of the informant, and usually in the presence of another moadón member, over a cup of tea and homemade Turkish pastry. Other house visits were of a more formal nature, either where an appointment had been formally made on a previous occasion, and where the conversation was one-toone, or else where I would knock on the door of an unknown person and would thereby be admitted.

Other informal settings for gathering data consisted of places in and around the Maxané Yehudá marketplace. Conversations, some in interview style, were conducted with shopowners (barbers, vegetable vendors, dried-goods merchants, and so on). Conversations were held repeatedly with a group of older men, post-I 948 immigrants, who cleaned and otherwise prepared vegetables for sale in the marketplace.

In addition, a series of visits were made to Judeo-Spanish speaking Sephardim 
living in an old-age home located in another heavily Sephardic-populated section of Jerusalem, Katamon. Visits to the old-age home were particularly fruitful since they enabled me to record conversations between two generations of JudeoSpanish speakers: the Hebrew-dominant adult offspring of old, bilingual Sephardim, and the parents themselves. Finally, conversational data from Judeo-Spanish speakers were gathered from a more highly educated group of Sephardim, post-World War II immigrants who are actively involved in maintaining the language and culture of Sephardim in Israel. This meant recording meetings of the Judeo-Spanish Society and ordinary conversations that took place in the offices of Kol-Yisrael (the Voice of Israel), the national radio network, which airs a daily program in Judeo-Spanish.

As for gathering data from the Latin American informants, since they are not concentrated in specific neighborhoods, fieldwork was accomplished through the use of network associations. Each family that was visited passed on to me the name and address of another family. The sample that resulted reflected an upper income, highly educated group (college and graduate school education) of relatively young people (under 35), with children who were either born in Israel or had arrived before the age of six. The Latin Americans contrasted sharply with the older Sephardim, who, on the whole, had a low level of education (particularly the women, many of whom were illiterate, both in Judeo-Spanish and in Hebrew). ${ }^{13}$ Much of the speech derived from the Latin Americans was particularly natural because it was taped in the complete absence of any investigator, for several of the families offered to tape family sessions (e.g., meals, bathing of children, after-dinner livingroom conversations) with their own recording equipment, and later passed on the taped materials to me.

\section{The informants}

Code-switching data from a total of eighty-seven persons were gathered; of the eighty-seven, 6I percent were female and 39 percent male. Their ages ranged from four to ninety-one, the mean age being 53.7 years. Of the eighty-seven informants, five were twelve-years-old or under, these being the children of Latin American Spanish speakers. All the remaining respondents were twentyfour or older.

Nearly half ( 42.5 percent) the respondents were born in what is now the State of Israel, 3 I percent were born in the Balkans (specifically, in order of frequency, Turkey, Yugoslavia, Greece, and Bulgaria), 17.2 percent in Latin America, and 9.2 percent in the Middle East (Syria, Egypt, Morocco) ${ }^{14}$ Among the 57.5 percent of the respondents who had immigrated to Israel, 48.8 percent had come to Israel in early childhood (0-7 years of age), I0.7 percent had come in preadolescence (8-13 years old), 10.7 percent had come in adolescence ( $14-18$ years old), and 29.8 percent had come as adults (over I 8 ). This means that virtually half the immigrants had arrived in early childhood, an age at which nativelike acquisition of a language is virtually guaranteed. If one adds to this 
group those who had come as preadolescents, an age where nativelike language acquisition is still high, one finds that 59.5 percent of the immigrants had arrived in Israel prior to adolescence, the implication of which being the expectation that this group would demonstrate a high level of bilingual ability. In sum, 76.7 percent of the respondents have native or nativelike competence in Hebrew. ${ }^{15}$

Low level of education was characteristic of the respondents as a whole. Over half the informants ( 56.5 percent) had an education of six years or less. When broken down into four levels of education $(0-3$ years $=$ low, 4-6 years $=$ midlow, 7-12 = mid, college and higher $=$ high), the distribution of schooling among the informants is as follows: 43.5 percent are in the low category, 12.9 percent are in the mid-low category, 22.4 percent are in the mid, and 21.9 percent are in the high group. Education is clearly associated with age ( $r=$ -.57 ), that is, the older the speaker, the fewer the years of schooling. ${ }^{16}$

Low levels of income were also predominant. Income was broken down into four categories: very low, mid-low, middle, and high. Again, over half the respondents ( 54.8 percent) fall into the very low and mid-low categories, and among them the majority (39.5 percent of the total sample) are in the very low category. The high income category comprises 31 percent of the informants. ${ }^{17}$

Information concerning the ethnic and historical background of informants was synthesized as a demographic variable called "ethnic-historical group membership," to determine if code-switching behavior was correlated with personal ethnic history and age of arrival at significant stages in Israel's history. Such a variable was devised because it was hypothesized that persons born or arriving in Ottoman-ruled Palestine would have a different command of Hebrew than would their offspring born during the British Mandate period, and that the latter, in turn, might behave linguistically differently from those persons who had arrived as children during the Mandate, and differently from those who had arrived as adults during the same period. Similarly, it was expected that the most recent arrivals in Israel, the post-World War II Balkan immigrants and the Latin Americans, could be distinguished both from each other and from the other groupings. Consequently, the sample was broken down into seven ethnic-historical groups: (I) born in Ottoman-ruled Palestine, (2) came as child to Ottoman-ruled Palestine, (3) came as child during British Mandate, (4) came as adult during British Mandate, (5) offspring of persons in any of the preceding categories (i.e., born in Israel during the period of the Mandate or later), (6) came from Europe as adult during the State of Israel period, and (7) came as adult from Latin America.

An additional factor hypothesized to be relevant to bilingual ability and, consequently, to code-switching behavior, was the number of generations of the informant's family that had lived in Israel. It was thought that persons who themselves had been born in Israel, and whose parents, and even grandparents, had been born there, might have a different competence in Hebrew from those whose parents had immigrated to Israel, and whose dominance in Hebrew was consequently not as high as their own. The informants were thus divided along 
the lines of number of generations living in Israel. It was found that 64.2 percent of the sample was first-generation Israeli. Of the remaining 35.8 percent who were born in Israel, most were second generation ( 19.8 percent of the sample). A total of 7.4 percent of the sample was third generation, and the remaining 14.7 percent of the sample ranged between fourth and eighth generation.

For the purpose of distinguishing those persons who spoke Spanish as a mother tongue from those who did not, the informants were categorized according to whether or not their mother was a fluent Spanish speaker. ${ }^{18}$ This variable allows one to distinguish the Arabic mother-tongue informants who had learned Judeo-Spanish in Ottoman Palestine from those informants who had spoken Judeo-Spanish within the home. Apparently, Judeo-Spanish was the language of street play among Sephardic children growing up within the walls of Old Jerusalem, and Arabic-speaking Jewish children acquired Judeo-Spanish from their Sephardic peers, inasmuch as up until the present century the Sephardim and their language were the most influential among the various Jewish ethnic/linguistic groups living there. ${ }^{19}$ For the present sample, it was found that 80.5 percent of the informants were offspring of Spanish-speaking mothers and 19.5 percent were not. Some of the persons included in the 19.5 percent were Latin Americans whose Ashkenazic parents had immigrated to Latin America from Europe.

One final characteristic noted for each informant was his/her degree of bilingualism. Using the criterion of observed bilingual ability, each informant was classified as either (I) fluent bilingual, (2) Spanish dominant, or (3) Hebrew dominant. The persons fitting into the fluent, or balanced, bilingual category tended to be the older people who were either born in Ottoman or British Mandate Palestine or else who had come during either of those periods as children or adolescents. The Spanish-dominant persons were those who had come as adults from Europe to the State of Israel (i.e., the post-I 948 period). Hebrew-dominant informants tended to be persons born in Israel, of middle age (about 45) and younger. The Latin Americans, who are the most recent wave of immigrants to Israel among the subgroups of the sample, surprisingly constitute a heavily bilingual group. This has mainly to do with their extensive formal study of Hebrew both prior to and after their arrival in Israel, and the fact that they tend to have gone through university-level education in Israel. This puts their Hebrew ability far above that of low-educated persons from the Balkans who may have been living in Israel for twenty years longer than they.

\section{METHODOLOGY}

\section{Coding procedures}

Criteria for determining a code-switch from a noncode-switch were degree of integration of the item into the base language of the sentence. ${ }^{20}$ Following Poplack (198I), a given item was considered to have been code-switched so long 
as it was not at the same time phonologically, morphologically, and syntactically integrated into the base language. For example, in ( 1 ), the noun bubəz 'dolls' is phonologically Spanish (main word stress is on the penultimate syllable); it is morphologically Spanish (ends in Spanish plural ending $-s$, realized as [z] postvocalically in many Judeo-Spanish geographical dialects, rather than the Hebrew feminine plural noun market -ot); and it is syntactically Spanish (follows an indefinite article, which in turn is preceded by a copula, estar. ${ }^{21}$ Neither article nor copula would be present in the equivalent Hebrew sentence.

(I) Kómo ke stan únas búbəz. ${ }^{22}$

As if they were dolls.

Because of the special language contact situation that Judeo-Spanish has had with Hebrew over the centuries, many items that might seem at first glance to be codeswitches are in fact old Hebrew borrowings that Judeo-Spanish had integrated into its lexicon prior to the arrival of Sephardim in Israel in this century. Therefore, a decision had to be made as to the code-switching status of each such item, these being predominantly single nouns. For instance, if alternate pronunciations existed for a Hebrew word known to have been part of the Judeo-Spanish lexicon in Europe, only the variant having Modern Israeli Hebrew pronunciation was counted as a codeswitch. Stress placement, for example, often distinguishes between old loan words and codeswitches, as in Judeo-Spanish (hereafter J-S) yešiva 'school of Jewish religious studies' versus Hebrew (hereafter $\mathrm{H}$ ) yešivá; $\mathrm{J}-\mathrm{S}$ tsedáka 'charity' versus $\mathrm{H}$ tsedaká. Other doublets are distinguished by their final or initial consonant (e.g., J-S šabá or sabá 'Sabbath' versus H šabát; J-S purín or puri 'Jewish holiday of Purim' versus $\mathrm{H}$ purim ${ }^{23} \mathrm{~J}-\mathrm{S}$ xamés 'food containing leavening agents' versus $\mathrm{H}$ xaméts). When no such doublets existed for a given Hebrew lexical item, and that fact can be attested by analyzing the speech of European Sephardim who had never lived in Israel (Crews I935; Nehama 1977), items were not counted as codeswitches. Examples of such frequently occurring items are: mazál 'luck, fortune'; mišpaxá 'family'; torá 'sacred Jewish law'; ben-adám 'person, human being'; xaxám 'wise, learned man'.

Also excluded as codeswitches were proper nouns: names of persons, places, buildings (i.e., names of famous stores, monuments, and so on). An exception was made whenever the Spanish and Hebrew equivalent of a proper noun occurred in the verbal repertoire of one and the same individual. Thus, often informants referred to the Old City as $\mathrm{H}$ ir atiká 'Old city' and at other moments in their discourse would call it J-S la sivdát vyéža 'the Old City'. Similarly, many persons usually referred to the Hebrew language with the Hebrew name ivrit, but on occasion used the Spanish name, ebréo. This was very often the case for the Latin American informants.

Discourse factors were taken into account in deciding whether a given constituent was a codeswitch or not, both at the intersentential level and at the intrasen- 


\section{LINGUISTIC CONSTRAINTS ON CODE-SWITCHING}

tential level. Thus, it was decided to count a given sentence as a codeswitch not only if a speaker changed from one language to another between sentences in his or her own monologic stretch of speech, but also if the speaker's sentence was in a different language from an immediately prior sentence uttered by another speaker. In other words, the decision to code the Hebrew elements in the second sentence of (2b) as codeswitches is a decision made at the level of discourse. Similarly, the decision to categorize the basic language of a given sentence as Spanish or Hebrew was arrived at not merely on the basis of frequency of words in one language versus the other, but also on the basis of the language of the speaker's immediately prior sentence. For example, in the dialogue of (2), speaker B's second sentence must be seen as a Spanish sentence in which the conjunction ával and nouns parašá and tefilá are code-switched elements, as are the noun phrase beyt aknéset and the conjunction az.

(2) a. ke dixo el rav?

What did the rabbi say?

b. La mísma parašá ke avía en šabát. Ával

The same scriptural portion that there was on Sabbath. But

parašá, tefilá ke se áze al beyt aknéset,

(the) scriptural portion, (the) prayer that is done in the synagogue,

al kal, az todos ya saven kwalo es.

in the synagogue, so everybody already knows what it is.

The category sentence constituted one type of intersentential codeswitch.

(3) "No," díšo el marído, "si afilú le van a kortár

"No," said her husband, "even if they are going to cut off

el pye a Malká, yo la vo tomár. Aní ikárti otá

Malkás foot, I am going to take her. I knew her

im šte regláyim.",

with two legs."

The Hebrew sentence beginning with Aní is thus coded as a sentence switch from Spanish to Hebrew.

Also counted as sentences are quotations, a popular narrative device used by informants. They are bracketed by expressions like, "He said," although the bracketing device may be at the beginning, middle, or end of the sentence. Note the contrasting position of the bracketing expressions in (4) and (5) below. Note, also, the embedded sentential quote in (6), which is followed by what is syntactically a new sentence in Spanish, however, one having no pause mechanism in between.

(4) Le díši "ma aní asé?",

I said to her "What am I to do?" 
(5) "Ma yeš?" le digo. "Š̌̌, givéret, ma at tsoéket!" "What's the matter?" I say to him. "Sh, madam, what are you shouting about!"

(6) I díšo Éster "Aní rašámti otáx a ti tiskriví, yom šiši (pause) And Esther said "I notified you I wrote to you, Friday

vaz estár a las tres abášo."

you're going to be downstairs at three o'clock."

Other types of constructions coded under the category of intersentential switches are tags (e.g., H naxón? 'right?'; J-S entendítes? 'did you understand?'), interjections (e.g., $\mathrm{H}$ bétax! and $\mathrm{H}$ beemét 'of course!'), idiomatic expressions (e.g., J-S sána y rézya '(be) healthy and strong,' i.e., an expression of farewell; $\mathrm{H}$ šalóm šalóm 'Well, hello,' i.e., a greeting; $\mathrm{H}$ xas vexalíla 'God forbid'), and negative and affirmative particles (e.g., $\mathrm{H}$ ken ken 'yes, yes'; $\mathrm{H}$ lo 'no'; J-S si si 'yes, yes').

The expansive category of intrasentential switches consisted of large constituents (independent clause, coordinate clause, subordinate clause, prepositional phrase, adverbial phrase) and smaller constituents (determiner, noun, noun phrase, verb, verb phrase, pronoun, adjective, adverb, preposition, subordinate conjunction, coordinate conjunction, interrogative words, and clause marker). ${ }^{24}$ Examples (7)-(22) demonstrate each type of codeswitch. ${ }^{25}$
NOUN
(7) Tóma xómer pára la univérsita.
She's taking material for the university.
NOUN PHRASE
(8) I agóra la metyó en mošáv zkením.
And now he put her in (an) old age home.
VERB
(9) Pára no enfasyár la mišaxá, lo lenednéd a la mišpaxá. In order not to bother the family, not to bother the family.
VERB PHRASE
(10) Taamín li ke no savíya. Believe me she didn't know.
PRONOUN
(11) Ze kómo la vedrá. That's like the truth.
ADJECTIVE
(12) Éra raxmaniyá, tová tová. She was compassionate, very good.
ADVERB
(13) Afílu yay vezes ke de díya estó en káza a las trez. There are even times that during the day I'm home at three o'clock.
ADVERBIAL.
PHRASE
(14) Pwéde ser lo tópas bemikré. You might meet him by chance.
PREPOSITIONAL (15) Ay un ómbre akí, vyéne káda dos semánas a kitár a las vyéžas a PHRASE
CONJUNCTION kaminár, bli késef. There's a man here, comes every two weeks to take the old women out for a walk, without money (for free).
(16) Yo bébo Néskave. Ával téngo kavé, ával, . . bébo Néskave. I drink instant coffee. But I have coffee; however, I drink instant coffee.
iNTERROGative (17) No se ma lax le te stan avlándo. I don't know what they're saying to you. 


\section{LINGUISTIC CONSTRAINTS ON CODE-SWITCHING}

\begin{tabular}{|c|c|c|}
\hline INTERJECTION & (18) & $\begin{array}{l}\text { Yála, }{ }^{26} \text { bévi maz. } \\
\text { Come on, drink more. }\end{array}$ \\
\hline IDIOM & (19) & $\begin{array}{l}\text { Ya básta, barúx ašém, ya básta. } \\
\text { It's enough already, thank God, it's enough already. }\end{array}$ \\
\hline TAG & $(20)$ & $\begin{array}{l}\text { Se sta kitándo la káska entéra, naxón? } \\
\text { One takes off the entire peel, right? }\end{array}$ \\
\hline $\begin{array}{l}\text { NEGATIVE } \\
\text { PARTICLE }\end{array}$ & $(21)$ & $\begin{array}{l}\text { Lo, "oréža," muzótros dizémos "la oréža." } \\
\text { No, "ear," we say "the ear." }\end{array}$ \\
\hline $\begin{array}{l}\text { AFFIRMATIVE } \\
\text { PARTICLE }\end{array}$ & (22) & $\begin{array}{l}\text { Ken, pára pésax te dyéron. } \\
\text { Yes, for Passover they gave you (some). }\end{array}$ \\
\hline
\end{tabular}

\section{FINDINGS}

Among the most salient findings is the fact that the single most often switched constituent was the noun (comprising 40 percent of all the codeswitches; see Table I for a summary). This stands in marked contrast to the findings of Gumperz (1976), Poplack (1980), and Wentz (1977), who found the sentence to

TABLE I. Syntactic categories of code-switching, by language

\begin{tabular}{|c|c|c|c|c|c|c|}
\hline \multirow{2}{*}{$\begin{array}{l}\text { Syntactic category of } \\
\text { switch }\end{array}$} & \multicolumn{2}{|c|}{ Spanish to Hebrew } & \multicolumn{2}{|c|}{ Hebrew to Spanish } & \multicolumn{2}{|c|}{ Total codeswitches } \\
\hline & $\mathrm{N}$ & $\%^{a}$ & $\mathrm{~N}$ & $\% a$ & $\mathrm{~N}$ & $\% a$ \\
\hline \multicolumn{7}{|l|}{ Intersentential: } \\
\hline Sentence & 444 & 12 & 66 & 2 & 510 & 14 \\
\hline $\begin{array}{l}\text { Exclamation, idiom, } \\
\text { tag, interjection }\end{array}$ & 786 & 21 & 2 & 0.05 & 788 & 21 \\
\hline $\begin{array}{l}\text { Negative and affirma- } \\
\text { tive particle }\end{array}$ & 55 & 1.5 & 4 & 0.1 & 59 & 2 \\
\hline \multicolumn{7}{|l|}{ Intrasentential } \\
\hline (Single) noun & 1,512 & 40 & 4 & 0.1 & 1,516 & 40 \\
\hline Noun phrase & 357 & 9 & 9 & 0.2 & 366 & 10 \\
\hline Verb & 0 & 0 & 4 & 0.1 & 4 & 0.1 \\
\hline Verb phrase & 12 & 0.3 & 25 & 0.7 & 37 & 1 \\
\hline Pronoun & 10 & 0.3 & 0 & 0 & 10 & 0.3 \\
\hline Adjective & 127 & 3 & 1 & 0.03 & 128 & 3 \\
\hline Adverb & 136 & 4 & 2 & 0.05 & 138 & 4 \\
\hline Adverbial phrase & 1 & 0.03 & 0 & 0 & 1 & 0.03 \\
\hline Subordinate conjunction & 103 & 3 & 0 & 0 & 103 & 3 \\
\hline Coordinate conjunction & 49 & 1 & 2 & 0.05 & 51 & 1 \\
\hline Prepositional phrase & 18 & 0.5 & 2 & 0.05 & 20 & 0.5 \\
\hline Interrogative & 9 & 0.2 & 1 & 0.03 & 10 & 0.3 \\
\hline Subordinate clause & 4 & 0.1 & 2 & 0.05 & 6 & 0.2 \\
\hline Coordinate clause & 4 & 0.1 & 5 & 0.1 & 9 & 0.2 \\
\hline Independent clause & 11 & 0.3 & 3 & 0.08 & 14 & 0.4 \\
\hline Clause marker & 1 & 0.03 & 0 & 0 & 1 & 0.03 \\
\hline Totals & 3,639 & $96 \%$ & 132 & $4 \%$ & 3,771 & $100 \%$ \\
\hline
\end{tabular}

Note: ${ }^{a}$ For percentage figures, numbers above 1.0 are rounded. 
be the most highly switched constituent, but corroborates the findings of McClure (1977) and Ornstein (1976). The next most frequently switched constituents were the smaller intersentential ones (namely, tags, interjections, idiomatic expressions, and exclamations). Taken together, these comprised 2 I percent of all the codeswitches. The only other category that accounted for a large portion of the code-switching material was the sentence. This made up 14 percent of the codeswitches, to be followed in importance by noun phrases, which constituted 10 percent of the data. Thus, four categories accounted for 85 percent of the switches, the remaining 15 percent comprising all the other categories. Significantly, clauses, which make up 8.5 percent of Poplack's (198I) codeswitches, comprised only .8 percent of the ones found in the present data.

In contrast to Poplack's finding that intersentential codeswitches occur equally as frequently as intrasentential ones (in her case, about half the data), in the present data intersentential code-switching played a far less important role (comprising 37 percent of the switches, leaving intrasentential switches with the bulk of the data, or 63 percent of all switches).

Furthermore, large-sized constituents make up only 2 percent of all intrasentential codeswitches, whereas small-sized constituents comprise 98 percent. This is an almost complete reversal of Poplack's ( 1980 ) results, in which 60 percent of the intrasentential switches are large constituents. The importance of this contrastive finding is that Poplack uses her results to support the equivalence constraint, whereas the evidence taken from the Spanish/Hebrew switches serves to undermine that conclusion.

Whereas in Poplack's (1980) Spanish/English data set the percentage of switches to English were about the same as that of switches to Spanish, a fact which Poplack ( $1980: 603$ ) uses to provide "further evidence for the suggestion that the code-switching mode proceeds from a single grammar,' in the Spanish/Hebrew data set 96 percent of the total codeswitches were in the same direction (namely, from Spanish to Hebrew). The miniscule amount of Hebrewto-Spanish code-switching is a function of the predominant tendency on the part of the speakers to use long all-Hebrew stretches of discourse. This was partially conditioned by the sudden involvement of a non-Spanish speaking interlocutor or listener (e.g., an Arabic/Hebrew bilingual). This pattern contrasted sharply with the relative scarcity of all-Spanish stretches of discourse, completely free of Hebrew lexical items. Furthermore, as Table I demonstrates, of the relatively few Hebrew-to-Spanish switches that did occur, nearly 50 percent (66 out of 132) were sentence-sized constituents. All this leads one to the conclusion that switching to Hebrew from a Spanish-based sentence is relatively easy, whereas switching to Spanish from a Hebrew base is syntactically quite difficult. ${ }^{27}$

This finding of course raises the question as to whether type of codeswitch (that is, intrasentential versus intersentential, and within the intrasentential type, large constituent versus small one) is related to degree of bilingual ability. 
According to Poplack's ( 1980 ) findings, people who are not fluent bilinguals will tend to rely heavily on intersentential code-switching, making only minimal use of the intrasentential type, and within the category of intrasentential code-switching, fluent bilinguals will make greater use of large-sized constituents. My findings strongly contradict these (see Appendix).

Keeping in mind that the informants were subdivided into three groups, according to bilingual ability, and using analysis of variance as a statistical technique, ${ }^{28}$ one finds no significant differences (F-test criterion) distinguishing the groups in terms of their use of intrasentential code-switching (their mean use of this type of code-switching ranging between .6I and .65). Similarly, the three linguistic subgroups behave in a similar manner (that is, no statistically significant difference among them emerges), insofar as intersentential code-switching behavior is concerned (the means among the three groups ranged between .34 and .38). In parallel fashion, no significant differences emerged among the three groups as to large-type intrasentential switching; nor could the three bilingual types be distinguished by a differential use of small-sized intrasentential switches.

In fact, if one tries to predict intra- versus intersentential switching via other characteristics of the informants (their education, income, age at arrival in Israel, number of generations of living in Israel, Spanish-speaking ability of informant's mother, ethnic-historical group membership), one finds that with the exception of one variable, ethnic-historical group, all other subgroups behave similarly (i.e., without statistically significant differences). Where ethnic-historical group is a distinguishing factor is in the subgroup of post-I 948 European immigrants, who used intrasentential code-switches significantly more often than the other respondents $(\mathrm{sig} .=.04)$. This, in fact, is consistent with the hypothesis that degree of bilingualism is related to type of codeswitch in that the post- I948 immigrants from the Balkans, as a group, are Spanish-dominant, and thus, having a lower level of competence in Hebrew, avoid the grammatically more complicated intrasentential switches in favor of the less grammatically difficult intersentential switches. However, no relationship was found between ethnichistorical group membership and size of constituent within the intrasentential category.

The only other significant relationship that was found was that between sex of informant and switching of small-sized intrasentential constituents (sig. $=.03$ ). Women had a somewhat higher mean (.64) use of small constituents than did men (.53), a finding consistent with Poplack's. Why there should be such a relationship is not easily explained. Perhaps the widely found correlation between female sex of speaker and greater sensitivity to social skills such as conversing is giving these particular women an edge over men in performing the more difficult verbal skill of code-switching at the level of small intrasentential constituents. Whatever the explanation, to reiterate, only three of the means of the scores in the Appendix were significant. 
SUSAN BERK-SELIGSON

TABLE 2. Code-switching errors

\begin{tabular}{lrr}
\hline \hline Type of error & $\mathrm{N}$ & $\%^{a}$ \\
\hline$\varnothing$ determiner & 122 & 66 \\
Extra determiner & 2 & 1 \\
$\varnothing$ copula or other verb & 22 & 12 \\
$\varnothing$ verb phrase & 3 & 2 \\
$\varnothing$ preposition & 23 & 12 \\
Extra preposition & 3 & 2 \\
$\varnothing$ conjunction & 3 & 2 \\
Word order & 4 & 2 \\
Presence of Hebrew noun & 2 & 1 \\
$\quad$ object marker $(e t)$ & 1 & 0.5 \\
$\varnothing$ (object) pronoun & 1 & 0.5 \\
Adverbial phrase & 186 & $100 \%$ \\
Total & \\
\hline \hline
\end{tabular}

Note: aPercent figures are rounded for numbers above 1.0 .

\section{Code-switching errors}

One of the main pieces of evidence used to support the equivalence constraint has been the rarity of "code-switching errors," that is, ungrammatical combinations of $L_{1}$ and $L_{2}$. Poplack (1980, I98I) has found "virtually no ungrammatical combinations" in the code-switching of her informants. In constrast, the speech of my Israeli informants was filled with violations of syntax, predominantly of Spanish syntax, as they switched to Hebrew from a Spanish-based sentence. In total, I 86 code-switching errors were found (see Table 2).

The single most frequently made error was the omission of the Spanish determiner, either the definite article ( $e l, l a$ ) or the indefinite article (un, una) before a noun or noun phrase. Fully 66 percent of the code-switching errors made involved the absence of a determiner. An example of each is found in (23) and (24) below.

(23) a. Izítis taút.

You made (a) mistake.

b. Akí ay misrád abášo.

Here there is (an) office down below.

(24) a. I ánde ez kotél hamaraví, haír atiká, aí nasyó mi mádre.

And where (the) Western Wall is, the Old City, there my mother was born.

b. Éya kére mispár del telefóno de tu ížo.

She wants (the) telephone number of your son.

Examples (23a) and (23b) demonstrate the absence of an indefinite Spanish article before a Hebrew noun. Such cases can clearly be accounted for by 
Hebrew syntactic structural pressure; the indefinite article (equivalent of English $a$, an) does not exist as a grammatical category. ${ }^{29}$ Its meaning is implicitly understood, but not overtly represented. The case of (24a) and (24b) represents the absence of a definite Spanish article before a Hebrew noun or noun phrase. These examples demonstrate a violation of not only Spanish syntactic structure, but of Hebrew structure as well. In (24a) the noun phrase kótel hamaraví 'the Western Wall' should have the definite clitic marker $h a$ - prefixed onto the noun kótel, serving thus to indicate the definiteness of the noun phrase in a sentence which in Hebrew would have no copula. In (24b), in contrast, the absence of a definite article before the noun mispár in no way violates Hebrew syntactic structure, since Hebrew does not allow the definite article to occur initially in noun phrase structures of the Noun + Noun type. In such NPs, the article would precede the second noun as in 'mispár ha telefón'.

The question as to why the Hebrew definite article is omitted is difficult to explain, since its presence would not violate Spanish norms. However, the omission of a Spanish determiner is somewhat more understandable if we consider that the Hebrew determiner is a bound morpheme, prefixed onto its noun, whereas the Spanish determiner is a free morpheme. ${ }^{30}$ Perhaps the structural pressure of Hebrew prevents some bilingual speakers from preceding a Hebrew noun or noun phrase with an unbound determiner if they sense the bound nature of the Hebrew determiner, and this leads them to delete the determiner entirely. Nevertheless, this is true for only a limited number of speakers, since definite determiners, primarily Spanish ones, were in fact present most of the time they were called for. Even for speakers who tended to delete definite articles, there was variation in their speech. Examples $(25 a, b, c)$, originating from one and the same woman in her recounting of a Biblical passage, are a striking demonstration of the variety of ways in which bilinguals handle the definite article when switching into Hebrew.

(25) a. Víno kadóš bárux hu díšo, "Ez pára vuzótros la ley."

Came the Lord [literally, 'blessed be his name'] (and) said, "It is for you, the law."

b. I el kadóš bárux hu díšo, ". . .," And the Lord said, ". . ."

c. Víno hakadóš brux hu díšo, “. . ., Came the Lord (and) said, ". . ."

It should be noted that in (25a) the definite article before the Hebrew noun phrase is omitted entirely, whereas in (25c) it is inserted in Hebrew. Within the course of this narration, this speaker used all three alternatives available to her.

In (24b) the absence of a definite article before the Hebrew noun mispár 'number' violates the rules of determination in Spanish. In the equivalent Hebrew sentence, furthermore, the Hebrew case marker $e t$, which would precede a definite noun or noun phrase when it is the object of a verb, is missing as well, albeit its 
presence or absence fits into the category of a sociolinguistic variable. It is striking that given that there were 1,516 code-switched nouns and 366 noun phrases, only twice did the object case marker et occur. This is not surprising given that there is no equivalent grammatical entity in Spanish. The use of $e t$ preceding a Hebrew noun or noun phrase in a Spanish-based sentence would be a violation of the equivalence constraint, insofar as Spanish syntax is concerned. Omission of the marker $e t$ in such a sentence would equally constitute a violation of the equivalence constraint from the point of view of Hebrew syntax, unless one considered the absence of $e t$ as a form of nonstandard Hebrew. In a case such as this, where the syntactic structure of the two languages is not parallel, it would be hypothesized that speakers would avoid such constructions. However, given the frequency with which noun as object of verb occurs both in Spanish and in Hebrew, it is no wonder that such avoidance is not possible, particularly in light of the fact that nouns comprised 40 percent of the codeswitches. Apparently, speakers preferred to violate the equivalence constraint in favor of Spanish when it came to a grammatical constituent which existed in one language but not the other, thereby doing away with the constituent entirely. However, their tendency to break both Spanish and Hebrew rules at one and the same time in their omission of the definite article is difficult to explain.

Interestingly, of the occurrences of $e t$ in a Spanish-based sentence, one is used incorrectly insofar as Hebrew is concerned, as can be seen in (26b).

(26) a. Sávez tu, et hapidgám, "El rey es kon la jénte alderedór."

Do you know the saying, "The king is with the people around him."

b. Éste ez axót gránde, axót rašít et ze la mužér.

This one is a head nurse, a head nurse is this woman.

The codeswitch in (26a), correct by Hebrew standards, was said by a highly balanced bilingual, one who has had a high level of education and has attained high literacy in both languages. ${ }^{31}$ Sentence (26b), in contrast, was uttered by a woman of mid-low education who had come to British Mandate Palestine as a young adult. She apparently reanalyzed $e t$ as a copula, to connect subject and predicate, instead of viewing it as a direct object marker.

The second most frequently made code-switching error was the omission of the copula (see (27a) and (27b) or some other verb (as in (27c)). This type of error occurred twenty-two times. It can be accounted for by the absence of a verblike copula in Hebrew present tense verb phrases. ${ }^{32}$ Sentences $(27 \mathrm{a}, \mathrm{b}$, and c) all occurred embedded within the context of Spanish discourse and are themselves Spanish-based.

(27) a. Ze kómo la vedrá.

That (is) like the truth.

b. La muzér axót.

His wife (is) (a) nurse. 
c. Afilu ambuláns, mil líras.

Even (the, a) ambulance (is, costs) a thousand liras.

For some speakers, particularly the poorly educated older persons born in the Old City, who are fluent bilinguals but often are illiterate or barely functionally literate, omission of the copula or other verb is a highly prevalent feature of their discourse, as (28) demonstrates. For clarity of illustration $\varnothing$ has been inserted wherever it is felt that Spanish would require some type of verb, copula, or otherwise. ${ }^{33}$

(28) Agóra fúman šabát, kamínan óto, ával akí, xas ve šalóm, no avíya. Today they smoke (on) Sabbath, they ride (in a ) car, but here, God forbid, there was no (such thing).

Šabát, šabát kódeš. ${ }^{34} \mathrm{Ni}$ gizár, ni ø óto, ni . . .

Sabbath, (is) holy Sabbath. Neither cooking, nor (riding in a) car, nor . . .

Ø Tefilá, vinír a káza, vizitár prímoz sérka, otra vez ø al kal. ø Šabát! (to say) Prayer, to come home, visit cousins nearby, (go) again to the synagogue. (That is) Sabbath!

The third most commonly made code-switching error was the omission of prepositions and prepositional phrases. Prepositions were omitted twenty-three times. The omission of prepositions, which violates both Spanish and Hebrew syntactic structure, is easily understandable when we consider the differential morphemic status of prepositions in the two languages. In Spanish, all prepositions are free morphemes, whereas in Hebrew, a large number of prepositions are bound morphemes, clitics that are prefixed onto their corresponding noun or noun phrase (e.g., be- 'in, at'; le- 'to'; me- 'from' ${ }^{35}$ ). Consequently, switching between a Hebrew clitic preposition and a Spanish noun or noun phrase would be violating the free morpheme constraint, and in fact, this was never done by any informant. Speakers avoided this pitfall by either using a Spanish preposition followed by a Hebrew noun or noun phrase, as in (29), where Spanish en 'in' is followed by the Hebrew noun phrase bet xolim 'hospital'.

(29) Se metyó en bet xolím ésta.

She, this one, put herself into a hospital.

Or else, speakers used a Hebrew prepositional phrase and thereby avoided the Spanish prepositions altogether, as in (30).

(30) Agóra begíl kazé ke me ága operasyón?

Now at this age, I should have myself an operation?

In (30), the Hebrew prepositional clitic be- is attached to the Hebrew noun gil 'age'. That speakers use one alternative just as easily as the other is demonstrated by ( $3 \mathrm{I}$ a) and ( $3 \mathrm{Ib}$ ), in which an elderly bilingual informant, born in the Old City, uses both types of constructions, one immediately following the other. 
(31) a. No, sólo a xag, baxág. Vyénen kon el pádre.

No, only on a holiday, on a holiday. They come with their father.

b. El nasyó élef téyša meót šalóš, agóra stamos en šmoním veaxát, naxón?

He was born (in) 1903, now we are in eighty-one, right?

Examples of code-switching errors involving omissions of prepositions are found in (32a) and (32b). In (32a), the preposition 'in' is missing before the noun ivrít 'Hebrew'.

(32) a. Unas kwántas palav́raz saviýa ivrít.

A few words he knew (in) Hebrew.

b. Un díya muz tumáron otobús a la sála gránde, gránde, One day they took us (by, in a) bus to the big, big hall,

asintádas i moz ízu neúm.

seated, and he made (a) speech for us.

In (32b) some type of preposition, by or in, should precede otobús 'bus'. The omission of the preposition violates both Spanish and Hebrew rules of syntax. More rare (three occurrences) is the error of using extra prepositions in the course of code-switching, as in the extra use of Spanish en with the Hebrew expression beemét 'really', as in "en beemét." This clearly is patterned after the Spanish constructions en serio 'really, truly', and en realidad 'really'.

Less commonly made code-switching errors involved incorrect word order, as in (33), the omissions of pronouns, as in (34), and the use of one kind of phrase (e.g., adverbial phrase) in place of another (e.g., noun phrase), as in (35).

(33) Gwénga axéret.

Another language.

(34) Ø Tóman pára firmár ke azítis livxór.

They take (it) in order to sign that you voted.

(35) Se vazér beséder gamúr.

They are going to make completely in order.

In (33), the words follow the Hebrew order of adjective succeeding noun. This happens to be the usual order of Spanish as well, except that the Spanish lexical item ótro 'another' is an exception to the rule, having to precede the noun which it modifies. The omission of the pronoun 'it' ( $\mathrm{S} \mathrm{lo}$ ) before the verb in (34) is a reflection of the absence of an impersonal pronoun in Hebrew syntax. The closest that Hebrew has in terms of a comparable constituent is the pronoun ze 'this' or 'it', but that pronoun would have to occur following the verb of which it is direct object, and preceded by the object marker et (i.e., Hem lokxím et ze 'They take it'). Finally, the type of error exemplified by (35), that is, the use of one type of phrase instead of another (beséder gamúr 'completely in order' is an adverbial phrase used in place of a noun phrase, 'complete order', which is what 
the speaker intended to say), is difficult to account for in terms of syntactic differences between Spanish and Hebrew. It might simply be a performance error, whereby the speaker may have made a mental shift in subject and did not bother to backtrack to make the appropriate syntactic alterations.

\section{The free morpheme constraint}

The preceding analysis of code-switching errors must lead one to the conclusion that the notion of the equivalence constraint as a universal constraint on codeswitching needs reevaluation. Although it seems to hold up fairly well for Spanish and English, recent evidence (Silva-Corvalán 1980) coming from MexicanAmerican bilinguals indicates that even in the alternation of Spanish and English, the equivalence constraint is often violated.

Little attention has been given to the question of how well the Spanish/Hebrew code-switching data stand up to the universally postulated free morpheme constraint. If one reviews all the instances of code-switching, only two instances occur in which the free morpheme constraint is violated (see (36) and (37)).

(36) Ze lo maanyén oti akonséžas haéle.

That's not interesting to me, those folktales.

(37) Pára ke no talfenéen a la mištará.

So that they wouldn't phone the police.

In (36), the noun phrase 'akonséžas' consists of the $\mathrm{H}$ bound definite article ha-, usually realized without the initial aspirated consonant in colloquial speech, and the J-S noun konséžas. There is no Hebrew pronunciation evident in the realization of the noun, the result being a J-S free morpheme attached to an $\mathrm{H}$ bound morpheme.

In (37) we see a Hebrew verb stem, talfén 'phone, call' attached to a Spanish verb ending, a bound morpheme. Again, the verb stem is phonetically Hebrew. This is a clear-cut case of a violation of the free morpheme constraint.

However, what gives greatest robustness to the free morpheme constraint is a negative sort of evidence. As has been mentioned in the context of frequency of each type of codeswitch, large intrasentential constituents were found rarely to be switched. There is a linguistic reason for this, and the reason lends support to the free morpheme constraint.

If we recall the fact that only 2 percent of all intrasentential codeswitches were of the large type, specifically clauses, this can be clearly accounted for by certain facts that distinguish Hebrew syntax from Spanish syntax, namely, that many kinds of clauses in Hebrew are introduced by bound morphemes, whereas the equivalent clauses in Spanish would be preceded by free morphemes performing a similar function. Particularly important here is the Hebrew conjunction ve'and', which conjoins coordinate clauses, as does the Spanish free form $i$ 'and'.

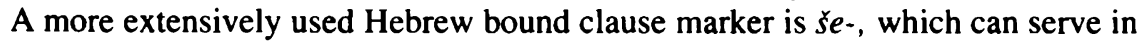
a multiple number of ways, such as relative clause marker, complementizer, 
introducer of "that"-clauses (see Berman [ I978] for an analysis of še-clauses). It is the contention of this paper that the differential morphemic status of Spanish free versus Hebrew bound clause markers is the explanatory factor accounting for the extreme scarcity of clause-switching in the Spanish/Hebrew case. Apparently, bilingual speakers are hesitant to violate the free morpheme constraint, since switching at the clause level following markers such as ve- and $\check{s} e$ - would violate the free morpheme constraint in either Spanish or Hebrew, depending upon which language the marker is drawn from. By contrast, the switching of clauses following Spanish $i$ 'and'; ke 'that, which, who'; el ke, el kwal 'who, that, which' poses no problem for Spanish/English bilinguals insofar as the free morpheme constraint is concerned. In fact, such clauses are highly switchable constituents, as has been mentioned in the review of the code-switching literature.

Further evidence in support of the free morpheme constraint comes from the code-switching errors discussed in the previous section, wherein either determiners or prepositions were omitted when Hebrew syntax calls for a bound morpheme and Spanish syntax requires a free one.

\section{CONCLUSIONS}

This paper has attempted to test the validity of three linguistic constraints on code-switching, purposefully choosing two languages that are syntactically more highly divergent from each other than are Spanish and English, the focus of most code-switching research. It has been found that the equivalence of structure constraint cannot be postulated as a universal in its present form. Either it must be restricted to use in describing the code-switching of languages that are syntactically similar or else it must be modified, to a weaker formulation. What this study has shown is that balanced bilinguals, time and time again, violate the equivalence constraint, producing sentences that are ungrammatical in either $L_{1}$ or $\mathrm{L}_{2}$ or both. Thus, for languages that are syntactically divergent, the equivalence constraint has been shown not to be valid.

Second, it has been demonstrated that size-of-constituent, as a constraint on code-switching, is also useful only in languages with similar syntactic structure. Spanish/Hebrew bilinguals largely refrain from switching large constituents in favor of smaller ones. Moreover, Spanish/Hebrew bilinguals are preponderantly intrasentential switchers, rather than intersentential ones, something which contradicts the current literature on code-switching, and which, once again, can be explained by the disparate nature of Spanish and Hebrew syntax.

In addition, type of code-switching (large versus small constituent, interversus intrasentential) is, with the exception of one minor case, unrelated to degree of bilingualism. That is, contrary to findings to date, balanced bilinguals, $\mathrm{L}_{1}$-dominant bilinguals, and $\mathrm{L}_{2}$-dominant bilinguals code-switch in an indistinguishable manner. This finding, therefore, strongly disputes the currently held 
notion that the ability to code-switch, particularly at the intrasentential level, is a mark of a bilingual's high competence in his/her two languages.

Third, using data of a negative kind, it has been asserted that the free morpheme constraint is, in fact, robust. The facts found to support the soundness of the free morpheme constraint are, first of all, the marked absence of clauseswitching among Spanish/Hebrew bilinguals, in contrast to Spanish/English bilinguals, who switch clauses with great frequency. The contrasting example posed by Spanish/Hebrew is accounted for by the presence of bound morphemes that introduce a variety of clauses in Hebrew, and the free morpheme status of comparable markers in Spanish. Second, code-switching errors in the form of omission of determiners and prepositions constitute another sort of evidence supporting the free morpheme constraint, since the absence of such categories contiguous to a code-switching point reflects their nonequivalent morphemic status in their respective languages. The conclusion, once again, must be that speakers refrain from switching at a syntactic point where the morpheme they must use has a different bound/free status in $\mathrm{L}_{1}$ and $\mathrm{L}_{2}$.

Finally, in regard to the issue of whether there is such a thing as a separate code-switching grammar, as Sankoff and Poplack (1979) have argued, or two separate grammars, the findings of the present study point to the latter. The twogrammar conception of code-switching and the rejection of a code-switching grammar has been emerging very recently in the work of other linguists (Doron 198I; Joshi I98I; Santa Ana I982; Woolford I98I).

It has been shown in this paper that speakers of varying degrees of bilingual ability engage in code-switching and that they all make use of the same types of code-switching. More importantly, they repeatedly switch at syntactic points where the grammars of $L_{1}$ and $L_{2}$ are not parallel and consequently produce "code-switching errors." This empirical finding would lead one to reject a grammar which consists of those overlapping areas of $L_{1}$ and $L_{2}$ that share the same syntactic structure. Speakers apparently do not avoid points of syntactic disparity, except where they involve the conflicting status of bound and free morphemes in the two languages. Thus, it is at the level of morphology that the equivalence constraint exerts its greatest pressure.

Obviously, additional studies need to be carried out on other syntactically disparate language pairs to determine whether what have been shown here to be weaknesses in the current formulation of the equivalence constraint and size-ofconstituent constraint are born out for other code-switched language pairs as well. In fact, recent evidence (Bentahila \& Davies 1983) from what is syntactically a remarkably parallel language-contact situation, that of French and Arabic, strongly supports the findings of this study. ${ }^{36} \mathrm{With}$ regard to the equivalence constraint, Bentahila and Davịes find that their French/Arabic code-switching data exhibit a number of violations of this constraint. They point to the acceptability of codeswitches occurring between subject and main verb in cases where French declarative main clauses require an SVO ordering of elements and Arabic 
clauses require a VSO order. Similarly, Bentahila and Davies find positive acceptability judgments regarding switching between adjectives and nouns in certain cases where French adjectives normally precede a noun, but where Arabic dictates that adjectives follow the noun. In addition, Arabic differs from French in that it requires an adjective within a definite noun phrase to be accompanied by a definite article, in addition to the definite article that accompanies the noun being modified. Bentahila and Davies find that whether a codeswitch in such a context violates French syntactic structure or Arabic structure, bilingual informants find the resulting sentences acceptable. Finally, the investigators find that French/Arabic bilinguals consider to be acceptable switches involving the omission of a relative pronoun in a relative clause, something permissible in Arabic, but a violation of surface syntax in French.

In addition to refuting the universality of the equivalence constraint, the study of Bentahila and Davies confirms what the present study has found, namely, the robustness of the free morpheme constraint. They mention, for example, the impossibility of switching between verb and clitic, and the general impossibility of an inflectional morpheme from one language accompanying a root morpheme from the other (Bentahila \& Davies I983:317). They conclude that they "need simply to postulate a constraint which states that code-switching is not possible across word-internal morpheme boundaries, similar to Poplack's (1980) Free Morpheme Constraint' (Bentahila \& Davies I983:3 I7). They qualify their statement, however, with the warning that this restriction is not absolute, and cite instances of switching between a root morpheme and an inflection. It is not clear from their example, however, if these are actually occurring forms or invented constructions used to elicit speaker judgments.

In conclusion, the study of French/Arabic code-switching supports the findings of the present study, indicating that the case of Spanish/Hebrew codeswitching is not unique among syntactically divergent languages used by bilinguals. ${ }^{37}$ Clearly, though, there is a need for further research to be carried out on other syntactically divergent languages that are in such intimate contact.

\section{NOTES}

*This is a revised version of a paper presented at the December 1982 meeting of the Linguistic Society of America, held in San Diego, California. Data collection for this study was supported by a National Science Foundation NATO Postdoctoral Fellowship in Science. Warm thanks go to Iggy Roca of the University of Essex and Brenda Danet of the Hebrew University of Jerusalem for their supportive role during the data-gathering stage of the study, and to Sarah Persellin and Jaime Ozkatán for their painstaking work of transcribing. I am also grateful to the various institutions that provided me with support at various stages of this project: in England, the Department of Languages and Linguistics of the University of Essex, the Girton College Library of Cambridge University for making available to me the Cynthia Crews Judeo-Spanish Archive; in Israel, the Communications Institute of the Hebrew University of Jerusalem, and the Ben Zvi Institute. Sincere thanks for their comments and suggestions relating to earlier drafts of this paper go to Adrian Akmajian, Ester Ben Tur, Oskar Bosko, William M. Christie, Jr., Adrienne Lehrer, Peter B. Machinist, and Mitchell A. Seligson. 
1. Code-switching is defined here as the alternative use of two or more languages within a single stretch of discourse, a sentence, or constituent.

2. Whereas Modern, or Israeli, Hebrew is certainly a more analytic language, typologically, than Classical, or Biblical, Hebrew, which was morphologically a highly synthetic language, it maintains, nevertheless, many of its original grammatical features, although they are used by the speech community in more restricted, specialized speech contexts. And while scholars of Hebrew debate the extent to which Israeli Hebrew has been affected by the features distinguishing Middle Hebrew from Classical Hebrew, on the one hand, and by Standard Average European, on the other (see the discussion in Blanc 1973; Blau 1981; Kutscher 1982; Rosén I977; Tené 1969), all would agree that the Hebrew spoken by the man or woman on the street in Israel can still be seen as retaining a solid core of Classical grammar.

3. A great deal of controversy has been aroused over the appropriate term by which to call this Spanish dialect. For one thing, scholars (Sephiha 1973a, 1973b) distinguish the vernacular, or spoken form of the language, from the written form, reserving the name "Ladino" for the latter. Ladino is the Spanish used in translations of the Bible and other religious texts. Its syntactic structure is very heavily influenced by Hebrew syntax, so that many sentences appear to be literal word-forword substitutions of Spanish lexical items in otherwise Hebrew-structured sentences. The spoken form of the language is alternatively called "Judezmo"' (or "Dhudezmo") (Bunis 1975, 1978; Gold 1974, 1977, I981, 1983, 1984, 1985), "Español" (by native speakers), "Spañolit" (the Hebraicized form of "Spañol"), and "Sefardit" (a Hebrew word denoting 'language of the Sephardic people'). The term "Judeo-Spanish" (or, the Hispanicized "Judeo-Español") is the one most often used by scholars (Armistead \& Silverman 1965, 1970, 1971; Baruch 1930; Besso 1952; Crews 1935, 1954-55; Harris 1979; Lapesa 198 I; Luria 1930; Malinowski 1979; Nehama 1977; Sala 1971, 1976; Sephiha 1973a, 1973b; Wagner 1923, 1930; Zamora Vicente 1979) perhaps because of its descriptive capability, and for this reason has been chosen for use in the present study as well.

4. Space does not allow for a documentation of the Hebrew-Aramaic lexical component of JudeoSpanish. It is known however, that from the time that Judeo-Spanish was recognized as a distinctive variety, it had a Hebrew-Aramaic component. Whether these lexical items constituted a substratum or had a different type of status in the language is not really of concern to this study; what is important to note is simply that they are known to have existed in Judeo-Spanish prior to the arrival of JudeoSpanish speakers to Israel in the twentieth century. The writings of Gold (I98I) and Weinreich (1956) shed light on the nature of that Hebrew-Aramaic component.

5. This can be explained by the mystique that the Spanish language held for the exiles, who had left a Spain in which for several centuries Jews had held an elite socioeconomic position (Harris 1979; Malinowski 1979), in a country which at the time of the Inquisition was geopolitically at its zenith. For the Sephardim, even centuries after their expulsion, Spain, or "Sepharad," as they called it in Hebrew, continued to symbolize the Siglo de Oro, or Golden Age, which Spain had been experiencing at the moment in which the Sephardim left. Consequently, for centuries afterwards, their descendants looked back upon Spain with nostalgia, and upon their Spanish language with pride.

6. Parfitt (1972:244) finds documentation in the letters of Scottish missionaries working in Palestine in 1839 , who noted that "the most of the Jews in this country speak Hebrew, many of them better than any other language . . . ," and that the "not uncommon European custom of speaking nothing but Hebrew on the Sabbath" was also prevalent in Palestine. He also has uncovered an article written in 1866 by a Mrs. J. Finn, the wife of the British Consul in Jerusalem, who, in attesting to the bilingual ability of Sephardim, stated that, "The Spanish Jews speak Hebrew with great ease" (Parfitt 1971:246).

7. Eliezer Ben Yehudah is credited with single-handedly revitalizing the language and propagating it as a mother tongue throughout the country. Exactly to what extent his efforts were successful with the Sephardim is not clear, although it is known that in Jerusalem, which because of its traditionbound orientation was the most resistant to accepting Hebrew as a means of communication for everyday purposes, the Sephardim were the most amenable to using Hebrew as a vernacular (Fellman 1973:1 14).

8. Some might argue that the fact that Hebrew had been spoken among the Sephardim to such a great extent before it became an official language in British-ruled Palestine is not at all surprising, given the internal conditions present before 1922 . Nevertheless, the formal step taken by the British mandatory power in establishing the official status of Hebrew must be viewed as having been highly 
influential in the ultimate evolution of Hebrew as the primary language of everyday communication in what later became the State of Israel.

9. The decision to analyze the code-switching of Latin American speakers together with that of Judeo-Spanish speakers was made on syntactic grounds: the fact that the syntax of Judeo-Spanish is essentially the same as that of Modern Spanish. What then distinguishes Latin American Spanish speakers from Sephardic Judeo-Spanish speakers is not the syntactic nature of their respective dialects, but their ethnic characteristics. Analytically, then, the two types of speakers can best be treated as different ethnic groups (i.e., an independent variable), membership in which may have an influence on frequency of code-switch type (i.e., the dependent variable). An analysis that confirms empirically the validity of this position appears in the Appendix, where the respondents are broken down by ethnic-historical groupings. The group that "Came as Adult from Latin America" (i.e., speakers of Latin American Spanish) exhibits code-switching behavior that is indistinguishable from that of the Judeo-Spanish speaking groups.

10. For a discussion of the difficulty in arriving at accurate current language usage data on JudeoSpanish speakers see Harris (1979:350) and Malinowski (I979:111).

II. The term "Oriental Jews" is used by Israeli social scientists and government officials to refer to Jews who have lived in North Africa and Western Asia. One linguist (Gold 1983) prefers to call this ethnic grouping by a name which refers to the language that the members speak, and thus uses the designation "Yahudic Jews" in favor of the more commonly used term "Oriental."

12. All phonetic transcriptions of Hebrew tokens presented in this paper reflect a casual style of pronunciation, that is, the pronunciation used by informants when they were in the investigator's presence. Thus, whereas careful pronunciation of the name of one of the fieldwork neighborhoods is [mazkéret mošé], since only the casual form [maskéret mošé] was heard, it was the latter form that was chosen to represent the name whenever reference was made to it in this paper. Similarly, since the formal pronunciation [mošáv zekením] 'old age home' was never heard, and only the casual [mosáv skením] was used, the second form was adopted for use in the narrative sections of this paper. 13. Information regarding the informants' literacy is based upon self-report. Each informant was asked if he or she could read. The informants were considered literate if they claimed to read any language, be it Modern Israeli Hebrew or Judeo-Spanish in either the Hebrew alphabet or the Latin alphabet.

14. Note that the term "Middle East" in this paper refers to all countries except Israel, since Israel is placed into a separate category for analytical purposes.

15. This is derived by summing the 42.5 percent of native-born respondents and the 34.2 percent of the immigrants who had arrived in Israel as either young children or preadolescents.

16. The significance level is .05 or better for this and all other associations measured in this paper. The negative association between education and age is simply a function of historical circumstances: the presence of a well-developed public education system in Israel during the British Mandate and Statehood eras, as opposed to the scarcity of public educational opportunities existing in Palestine, the Balkans, and the Middle East during the time of Ottoman rule.

17. These are persons with college education or higher and tend to be primarily the Latin Americans in the sample, as well as younger Judeo-Spanish-speaking immigrants from the Balkans who are currently working in some professional capacity. Most of the persons in the middle income group are the offspring of Sephardim who had either been born in Palestine or who had come in early childhood. In this sample, these offspring tend to be white-collar workers, often workers in government offices.

18. Fluency on the part of the mother could only be determined by reports of the informant, since in only a few instances was the informant's mother still living.

19. Actually, Judeo-Spanish was not only the language of street play, but also the normal everyday spoken language of the Sephardic population for all purposes.

20. All code-switching data were transcribed by college-educated bilingual Judeo-Spanish/ Hebrew-speaking Israelis. To guarantee reliability, the transcripts were then checked by a different Israeli bilingual, and for coding purposes, a third time by this investigator.

21. Many Judeo-Spanish speakers alternatively use estar for Standard Modern Spanish ser as the copula.

22. Note that all Spanish and Hebrew examples in this paper are presented in their original phonetic transcription. This means that some of the examples will emerge as nonstandard in some way (i.e., accented or morphologically divergent from the spoken standard). 


\section{LINGUISTIC CONSTRAINTS ON CODE-SWITCHING}

Two dialect zones in the Balkan areas where Judeo-Spanish was spoken, and still is minimally spoken, have been distinguished by dialect geographers. There must have been phonological variation within each, and certainly there is phonological variation in Israel now, that goes beyond the recognized norms of the two dialects. Thus, one might expect either li díši or le díše (example (4)), but in fact one can hear le dísi i, as in example (4). In Hebrew, too, nonstandard forms emerged. Thus, one might expect ragláyim for 'legs', but an old informant who learned Hebrew as a second language did say regláyim (example (3)). Phonetic variation abounds in connection with $\mathrm{e} \sim \mathrm{o}, \mathrm{o} \sim \mathrm{u}$, and $\mathrm{s} \sim \mathrm{z}$ preceding a voiced segment, as can be independently documented in Malinowski (I979).

23. Whereas even the forms šabát and purím existed in Judeo-Spanish, it is not known to what extent Judeo-Spanish speakers outside of Israel ever used these variants in conversation: They may have been restricted to the reading of religious texts. For the purposes of coding in this study, whenever forms such as šabát and purim occurred in what were otherwise Israeli Hebrew phrases or sentences, they were considered to be Hebrew tokens, otherwise they were counted as Judeo-Spanish items.

24. The decision to put noun phrase and verb phrase into the category of small intrasentential codeswitch was done for analytical purposes on an empirical basis, namely, NPs and VPs found in the sample were short constituents.

25. Examples are primarily Hebrew constituents switched into Spanish-base sentences, inasmuch as the overwhelming majority were of this type, as is shown in the following section of this paper. 26. The word yála is actually a slang exclamation borrowed from Arabic (ya Allah 'Oh God') but is prevalent in the Hebrew of all social strata of Israeli society, even among those whose knowledge of Arabic is minimal. For this reason, it is considered an incorporated loanword (meaning 'come on') and is accordingly coded as a Hebrew item in this study.

27. An additional possible explanation for the asymmetrical direction of switching is the greater prestige of Hebrew over Spanish in Israel. Such a conclusion, however, cannot be considered as highly explanatory as a syntactically based one, since a parallel situation in terms of language prestige exists for English and Spanish in the United States, namely, the official language enjoys greater prestige than the ethnic minority tongue, yet the direction of code-switching is symmetrical.

Additional possible factors that might account for the direction of switching are the bilingual proficiency of speakers and addressees. The conversational configurations in terms of speaker versus listener proficiency in Hebrew and Spanish were quite diverse: Conversational groupings varied from dyads to groupings of four, five, or six conversational parties, and bilingual ability was broken down into the three categories already mentioned, namely, Spanish-dominant, Hebrew-dominant, and relatively balanced bilingual. These two factors produced a wide variety of conversational groupings, the analysis of which in regard to direction of codeswitch would entail a separate study in itself. This study limits its focus to the analysis of speaker bilingual proficiency and grammatical codeswitch type. Clearly, however, the role of the speaker's perception of the language dominance of the listener may have been playing a role in the intersentential code-switching observed in the present study, since this factor has been shown in other studies to be influential in predicting the direction of language shift (Genishi I98I; McClure I98I; Zentella I98I). Intrasentential switching, however, would seem far less likely to be affected by this factor. What appeared to be going on was the shift from one language to another, intersententially, when a new participant entered the conversational group, notably one who was perceived as not being proficient in the language being used by the speaker at that moment. In conversational groupings larger than dyads and triads, it is suspected that the relative social standing of the listeners may also have been influential in causing a given speaker to adjust his or her language code to that of certain listeners in the group, rather than to others.

28. Analysis of variance was chosen for use rather than the technique of variable rule analysis. As Kay and McDaniel (I979:I52) have shown, variable rule analysis is "closely related both mathematically and philosophically" to analysis of variance, a position which Sankoff and Labov (I979) essentially accept. However, Sankoff and Labov argue that their log-linear approach is more suitable to linguistic data, because "data on a linguistic variable collected from a speech sample tend to be very unevenly distributed among the various possible contexts" (Sankoff \& Labov 1979:I93). In contrast to data successfully analyzed by the variable rule technique, the data in the present study, like Poplack's (1980), are analyzed to see how demographic and socioeconomic characteristics of the sample vary with linguistic items, rather than to discover how particular linguistic environments constrain a linguistic variable. In this light, the data being analyzed in this study are no different from 
the data that have been analyzed successfully with analysis of variance in many other sociological studies.

29. Informal Israeli Hebrew apparently is just beginning to use the interrogative adjective évze 'which' as an indefinite article. This usage is so new, however, that Israelis currently in their thirties who left Israel in their twenties have never heard of such a usage for éyze. Their rendering of a sentence such as 'Did you buy a book?' was exclusively article-free: Kaníta séfer? The use of éyze in this context consistently provoked the same reaction in a sample of recently emigrated Israeli informants living in the United States: éyze means 'which'.

30. Some linguists might argue that the Hebrew definite article is bound and the Spanish one unbound only in the written language. Similarly, then, one could argue that the English definite article, "the," is likewise bound in the oral medium. The issue of the boundedness of a morpheme must be dealt with empirically and needs to be investigated in its own right. Clearly, one would need both to tap the intuitions of a sufficient number of native speakers and to subject the morphemes to a variety of tests (e.g., pausability) to determine whether these morphemes are in fact free or bound. Certainly one important factor that would influence a native speaker's judgment as to the boundedness of a given morpheme is the element of literacy. Bilinguals who are literate in both Spanish and Hebrew would more readily perceive Spanish definite articles as being free and Hebrew ones as bound. It would be useful, then, to tap the linguistic intuitions of illiterate bilinguals and/or preliterate children.

31. This informant works as a broadcaster on a regularly aired Judeo-Spanish program on Israeli radio.

32. Hebrew does have overtly manifested copulas for other tenses (e.g., havá for past, yihyé for future). Furthermore, pronouns are often used as copulas in present tense verb phrases, usually for emphasis or clarity. The grammatical status of such pronouns when they are carrying out a verblike function is the cause of much heated debate among Hebrew linguists (Azar 1976; Berman \& Grosu 1976; Hayon 1971, 1973; Rubinstein 1968).

33. In discourse such as that found in (28), where the style of speech is casual, it is necessary to distinguish between fragmentary speech and grammatical error. The decision to count a given item as a code-switching error (in this case, copula or verb deletion) was based on the parallelism of adjacent grammatical constructions. For example, the decision to count the $\varnothing$ in the sentences beginning with

"Ni gizár . . ." and "Tefilá . . "' as errors was based on the fact that these sentences have certain phrasal styles which consist of strings of verb phrases (e.g., the neither-nor construction, which opens with a verb; the series of verb phrases conjoined by commas, that is, intonation phenomena, leading the listener to feel that verbs were not said but were needed to complete the parallelism of the overall sentence style).

34. Whereas the lexical constituents alone may not clearly indicate that this is a sentence, suprasegmental features such as an upward intonation at the end of sentence-initial Sabát, together with a clause juncture, followed by a downward intonation at the end of kódeš and a sentence boundary unequivocally indicate to the listener that this is a sentence.

35. Hebrew does have, however, free morpheme propositions, such as $̌ e l$, the possessive, and min 'from'.

36. It should be pointed out that the data-gathering procedures and nature of the sample in the Bentahila and Davies study are in several ways different from those of the present study and thus do not make for isomorphic comparability. In particular, the number of informants tape-recorded, while not actually reported, would seem to be small, judging by the 7.5 hours of total taped material and the fact that the recording was done in the setting of one household. Second, the data analyzed were not restricted to naturally occurring speech samples, but included as well the judgments of informants regarding code-switching sequences invented deliberately for the purpose of evaluation.

37. While the work of Bentahila and Davies is by no means the only study of code-switching carried out on a language pair other than Spanish/English, its relevance to the present study is the high degree of syntactic parallelism between French/Arabic on the one hand and Spanish/Hebrew on the other. Other studies that have examined code-switching between syntactically divergent languages are the work of Gumperz ( 1976) on Hindi/English and Slovenian/German, Kachru ( 1975) on Hindi/English, and Timm (1978) on French/Russian. Unfortunately, the conclusions of both Gumperz and Kachru are based entirely on acceptability judgments of informants, rather than on naturally occurring speech, and the findings of Timm are drawn from speech that is even further removed from natural speech, namely, the conversations depicted in a literary work of fiction (Tolstoy's War and 


\section{LINGUISTIC CONSTRAINTS ON CODE-SWITCHING}

Peace). Thus, they, as well, are difficult to generalize from and utilize for the purpose of comparison. Moreover, all three analyses present their findings as a series of ad hoc constraints and do not address the larger issue of universal constraints, which is the focus of the present study. For all these reasons, a comparison of the findings of these other studies with those of the present one is highly difficult.

\section{REFERENCES}

Alonso, M. (1962). Evolución sintáctica del español. Madrid: Aguilar.

Armistead, S., \& Silverman, J. (1965). Judeo-Spanish ballads in a MS by Solomon Israel Cherezli. In I. Langnas \& B. Sholod (eds.), Studies in honor of M. J. Benardete. New York: Las Americas. 367-87.

(1970). Exclamaciones turcas y otros rasgos orientales en el romance judeo-español. Sefarad 30:177-93. Press.

Azar, M. (1976). The emphatic sentence in modern Hebrew. In P. Cole (ed.), Studies in modern Hebrew syntax and semantics. Amsterdam: North Holland. 209-30.

Baruch, K. (1930). El judeoespañol de Bosnia. Revista de filología española 17:1 13-54.

Bentahila, A. \& Davies, E. E. (1983). The syntax of Arabic-French code-switching. Lingua 59:30 I30.

Besso, H. (1952). Bibliografía sobre el judeo-español. Bulletin hispanique 54:412-22.

Berman, R. A. (1978). Modern Hebrew structure. Tel Aviv: University Publishing Projects, Ltd.

Berman, R. A., \& Grosu, A. (1976). Aspects of the copula in modern Hebrew. In P. Cole (ed.), Studies in modern Hebrew syntax and semantics. Amsterdam: North Holland Publishing Company. $265-85$.

Blanc, H. (1973). Israeli Hebrew in perspective. Ariel 32:93-104.

Blau, J. ( $198 \mathrm{I}$ ). The renaissance of modern Hebrew and modern standard Arabic. Berkeley: University of California Press.

Bunis, D. (1975). Problems in Judezmo linguistics. (Working Papers No. I in Sephardic and Oriental Jewish Studies.) New York: The American Sephardi Federation.

(1978). Response to Denah Lida's paper on Ladino language and literature. In H. Paper (ed.), Jewish languages: Theme and variations. 93-102. Cambridge: Association for Jewish Studies.

Crews, C. M. (1935). Recherches sur le judéo-espagnol dans les pays balkaniques. Paris: Droz. (1954-55). Some Arabic and Hebrew words in oriental Judaeo-Spanish. Vox Romanica 14:296-309.

Doron, E. (198I). On formal models of code-switching. Manuscript, University of Texas at Austin.

Fellman, J. (1973). The revival of a classical tongue: Eliezer Ben Yehuda and the modern Hebrew language. The Hague: Mouton.

Genishi, C. (198I). Code-switching in Chicano six-year-olds. In R. P. Durán (ed.), Latino language and communicative behavior. Norwood, N.J.: Ablex. 133-52.

Gingrás, R. (1974). Problems in the description of Spanish-English intra-sentential code-switching. In G. A. Bills (ed.), Southwest areal linguistics. San Diego: Institute for Cultural Pluralism. 196775.

Gold, D. L. (1974). Review of L. S. Dawidowicz et al. (eds.), For Max Weinreich on his seventieth birthday: Essays in Jewish languages, literature, and society. Language Sciences 31:47-53. (1977). Dzhudezmo. Language Sciences 47:14-16.

(I98I). Recent American studies in Jewish languages (review essay). Jewish Language Review 1:1 I-88. (1983). Planning glottonyms for Jewish languages (with emphasis on Judezmo and Yahudic). Jewish Language Review 3:7 I-95.

(I984). Myths about the glottonym Judezmo. Jewish Language Review 4:126-41. (1985). More on the glottonym Judezmo. Jewish Language Review 5:1 51-53.

Gumperz, J. J. ( 1971 ). Bilingualism, bidialectalism and classroom interaction. In Language in social groups. Stanford: Stanford University Press. 
(1976). The sociolinguistic significance of conversational code-switching. (Working Papers of the Language Behavior Research Laboratory, No. 46). Berkeley: University of California. Gumperz, J. J., \& Hernández-Chávez, E. ( 1975). Cognitive aspects of bilingual communication. In E. Hernández-Chávez, A. Cohen, \& A. Beltramo (eds.), El lenguaje de los Chicanos. Arlington, Va.: Center for Applied Linguistics. 154-63.

Harris, T. K. (1979). The prognosis for Judeo-Spanish: Its description, present status, survival and decline, with implications for the study of language death in general. Ph.D. dissertation, Georgetown University.

Hassán, I. M. (1963). Perspectivas del judeo-español. Arbor 55:175-84.

Hasselmo, N. (1970). Code-switching and modes of speaking. In G. G. Gilbert (ed.), Texas studies in bilingualism. Berlin: de Gruyter. 179-210.

Hayon, Y. ( 1971). Relative clauses with nonverbal predicates. Hebrew Computational Linguistics Bulletin 4:7-68.

(1973). Relativization in Hebrew: A transformational approach. The Hague: Mouton.

Hirsch, R. (195I). A study of some aspects of a Judeo-Spanish dialect as spoken by a New York Sephardic family. Ph.D. dissertation, University of Michigan.

Huerta-Macías, A. (1981). Codeswitching: All in the family. In R. P. Durán (ed.), Latino language and communicative behavior. Norwood, N.J.: Ablex, 153-68.

Joshi, A. (198I). Some problems in processing sentences with intra-sentential code-switching. Paper presented at the University of Texas Parsing Workshop.

Kachru, B. (1975). Toward structuring the form and function of code-mixing: An Indian perspective. (Studies in the Linguistic Sciences 5.1.) Department of Linguistics, University of Illinois at Urbana.

$\rightarrow$ Kay, P., \& McDaniel, C. K. (1979). On the logic of variable rules. Language in Society 8:15I-87.

Kutscher, E. Y. (1982). A history of the Hebrew language. Jerusalem: The Magnes Press, the Hebrew University.

Lapesa, R. ( I98I). Historia de la lengua española. Madrid: Editorial Gredos.

Lipski, J. M. (1978). Code-switching and the problem of bilingual competence. In M. Paradis (ed.), Aspects of bilingualism. Columbia, S.C.: Hornbeam. 250-64.

Luria, M. A. (1930). A study of the Monastir dialect of Judeo-Spanish based on oral material collected in Monastir, Yugoslavia. New York: Instituto de las Españas.

Malinowski, A. (1979). Aspects of contemporary Judeo-Spanish in Israel. Ph.D. dissertation, University of Michigan.

McClure, E. (198I). Formal and functional aspects of the code-switched discourse of bilingual children. In R. P. Durán (ed.), Latino language and communicative behavior. Norwood, N.J.: Ablex. 69-94.

Nehama, J. (1977). Dictionnaire du judéo-espagnol. Madrid: Instituto Arias Montano.

Parfitt, T. V. (1972). The use of Hebrew in Palestine. Journal of Semitic Studies 17:237-52.

Pfaff, C. W. (1976). Functional and structural constraints on syntactic variation in code-switching. In B. Steever et al. (eds.), Papers from the parasession on diachronic syntax. Chicago: Chicago Linguistic Society. 248-59.

$\rightarrow$ (1979). Constraints on language mixing. Language 55:29I-3I8.

Poplack, S. (1980). "Sometimes I'll start a sentence in Spanish y termino en español": Toward a typology of code-switching. Linguistics $18: 581-6$ I 8 .

(1981). Syntactic structure and social function. In R. P. Durán (ed.), Latino language and communicative behavior. Norwood, N.J.: Ablex. 169-84.

Rosén, H. B. (1977). Contemporary Hebrew. The Hague: Mouton.

Rubinstein, E. (1968). Hamišpat hašemani (The nominal sentence). Tel Aviv: Hakibbutz HaMeuchad.

Sala, M. (1971). Phonétique et phonologie du judéo-espagnol de Bucarest. The Hague: Mouton. (1976). Le judéo-espagnol. (Trends in Linguistics. State-of-the-art Reports No. 7.) The Hague: Mouton.

$\rightarrow$ Sankoff, D. \& Labov, W. (1979). On the uses of variable rules. Language in Society 8:189-222.

Sankoff, D. \& Poplack, S. ( I 979). A formal grammar for code-switching. (Working Paper No. 8.) New York: Center for Puerto Rican Studies, CUNY.

Santa Ana, O. (1982). A basic language analysis of codeswitched sentences. Manuscript, University of Pennsylvania. 
Schmelz, U. O., \& Bachi, R. (1974). Hebrew as everyday language of the Jews in Israel - Statistical appraisal. In S. W. Baron (ed.), Jubilee volume II (English). Jerusalem: American Academy for Jewish Research. 745-85.

Sephiha, H. V. (I973a). Le ladino (judéo-espagnol calque), Deutéronome, versions de Constantinople (1547) et de la Ferrare (1553). Paris: Editions Hispaniques.

(I973b). The present state of Judeo-Spanish in Turkey. The American Sephardi 6:22-29.

Shaffer, D. (1978). The place of code-switching in linguistic contacts. In M. Paradis (ed.), Aspects of biligualism. Columbia, S.C.: Hornbeam. 265-74.

Silva-Corvalán, C. (1980). Code-shifting pattems in Chicano Spanish. Paper presented at the conference on Spanish in the U.S. setting: Beyond the Southwest. Chicago: University of IllinoisChicago Circle. To appear in L. Elías-Olivares \& D. Nasjileti (eds.), Spanish in the United States: Beyond the Southwest. Washington, D.C.: N.C.B.E.

Tené, D. (1969). Israeli Hebrew. Ariel 25:48-63.

Timm, L. A. ( 1975). Spanish-English code-switching: el porqué y How-Not-To. Romance Philology 28:473-82.

(1978). Code-switching in War and Peace. In M. Paradis (ed.), Aspects of bilingualism. Columbia, S.C.: Hombeam. 302-15.

Valdés-Fallis, G. (1976). Social interaction and code-switching patterns: A case study of Spanish/English alternation. In G. Keller et al. (eds.), Bilingualism in the bicentennial and beyond. New York: Bilingual. 53-85.

(198I). Code-switching as a deliberate verbal strategy: A microanalysis of direct and indirect requests among bilingual Chicano speakers. In $\mathbf{R}$. P. Durán (ed.), Latino language and communicative behavior. Norwood, N.J.: Ablex. 95-108.

Wagner, M. L. (1914). Beitrage zur kenntnis des Judenspanischen von Constantinopel. Vienna: Akademie der Wissenschaften Schriften de Balkankomission, Linguistische Abelitung II.

(I923). Algunas observaciones generales sobre el judeo-español de Oriente. Revista de filología española 10:225-44.

(1930). Caracteres generales del judeo-español en Oriente. Madrid: Hernando.

Weinreich, M. (1956). The Jewish languages of Romance stock and their relation to earliest Yiddish. Romance Philology 9:403-28.

Wentz, J. (1977). Some considerations in the development of a syntactic description of codeswitching. Ph.D. dissertation, University of Kansas.

Wentz, J., \& McClure, E. (n.d.). As cited on p. 175 in S. Poplack, Syntactic structure and social function of codeswitching. In R. P. Durán (ed.), Latino language and communicative behavior. Norwood, N.J.: Ablex. I69-84.

Woolford, E. (I981). A formal model of bilingual code-switching. Manuscript, Massachusetts Institute of Technology.

Zamora Vicente, A. (1979). Dialectología española. Madrid: Editorial Gredos.

Zentella, A. C. (1981). Tá bien, You could answer me en cualquier idioma: Puerto Rican Codeswitching in bilingual classrooms. In R. P. Durán (ed.), Latino language and communicative behavior. Norwood, N.J.: Ablex. 109-32.

APPENDIX

CODE-SWITCHING BY SOCIOECONOMIC AND DEMOGRAPHIC

CHARACTERISTICS: ANALYSIS OF VARIANCE

\begin{tabular}{|c|c|c|c|c|}
\hline $\begin{array}{l}\text { Category of } \\
\text { codeswitch }\end{array}$ & Category of group & $\begin{array}{l}\text { Group } \\
\text { mean }^{a}\end{array}$ & $\mathrm{~F}$ & Significance $b$ \\
\hline \multirow[t]{2}{*}{ Intersentential } & Sex: & .37 & & \\
\hline & $\begin{array}{l}\text { Female } \\
\text { Male }\end{array}$ & $\begin{array}{l}.34 \\
.42\end{array}$ & 2.47 & $\begin{array}{l}\text { NS } \\
\text { (continued) }\end{array}$ \\
\hline
\end{tabular}


APPENDIX (Continued)

\begin{tabular}{|c|c|c|c|c|}
\hline $\begin{array}{l}\text { Category of } \\
\text { codeswitch }\end{array}$ & Category of group & $\begin{array}{l}\text { Group } \\
\text { mean }^{a}\end{array}$ & $\mathrm{~F}$ & Significance ${ }^{b}$ \\
\hline & Place of birth: & .37 & & \\
\hline & $\begin{array}{l}\text { Israel } \\
\text { Middle East } \\
\text { Greece } \\
\text { Turkey } \\
\text { Yugoslavia } \\
\text { Bulgaria } \\
\text { Latin America }\end{array}$ & $\begin{array}{l}.34 \\
.41 \\
.29 \\
.55 \\
.35 \\
.39 \\
.31\end{array}$ & 1.57 & NS \\
\hline & Age on arrival in Israel: & .37 & & \\
\hline & $\begin{array}{l}0-7 \text { years } \\
8-13 \\
14-18 \\
\text { Over } 18\end{array}$ & $\begin{array}{l}.34 \\
.43 \\
.50 \\
.34\end{array}$ & 1.48 & NS \\
\hline & Education: & .37 & & \\
\hline & $\begin{array}{l}\text { Low } \\
\text { Mid-low } \\
\text { Middle } \\
\text { High }\end{array}$ & $\begin{array}{l}.38 \\
.32 \\
.43 \\
.33\end{array}$ & .76 & NS \\
\hline & Income: & .37 & & \\
\hline & $\begin{array}{l}\text { Very low } \\
\text { Mid-low } \\
\text { Middle } \\
\text { High }\end{array}$ & $\begin{array}{l}.39 \\
.31 \\
.46 \\
.32\end{array}$ & 1.30 & NS \\
\hline & Ethnic-historical group: & .37 & & \\
\hline & $\begin{array}{l}\text { Born in Ottoman } \\
\text { Palestine } \\
\text { Came as child to Ot- } \\
\text { toman Palestine } \\
\text { Came as child to } \\
\text { British Mandate } \\
\text { Came as adult to } \\
\text { British Mandate } \\
\text { Offspring born in } \\
\text { British Mandate or } \\
\text { Israel } \\
\text { Came as post-World } \\
\text { War II European } \\
\text { adult } \\
\text { Came as adult from } \\
\text { Latin America }\end{array}$ & $\begin{array}{l}.34 \\
.33 \\
.30 \\
.30 \\
.35 \\
.56 \\
.29\end{array}$ & 2.31 & .04 \\
\hline & $\begin{array}{l}\text { No. of generations in } \\
\text { Israel: }\end{array}$ & .37 & & \\
\hline & $\begin{array}{l}1 \\
2 \\
3 \\
4 \\
5 \text { and greater }\end{array}$ & $\begin{array}{l}.37 \\
.35 \\
.32 \\
.29 \\
.41\end{array}$ & .47 & NS \\
\hline
\end{tabular}




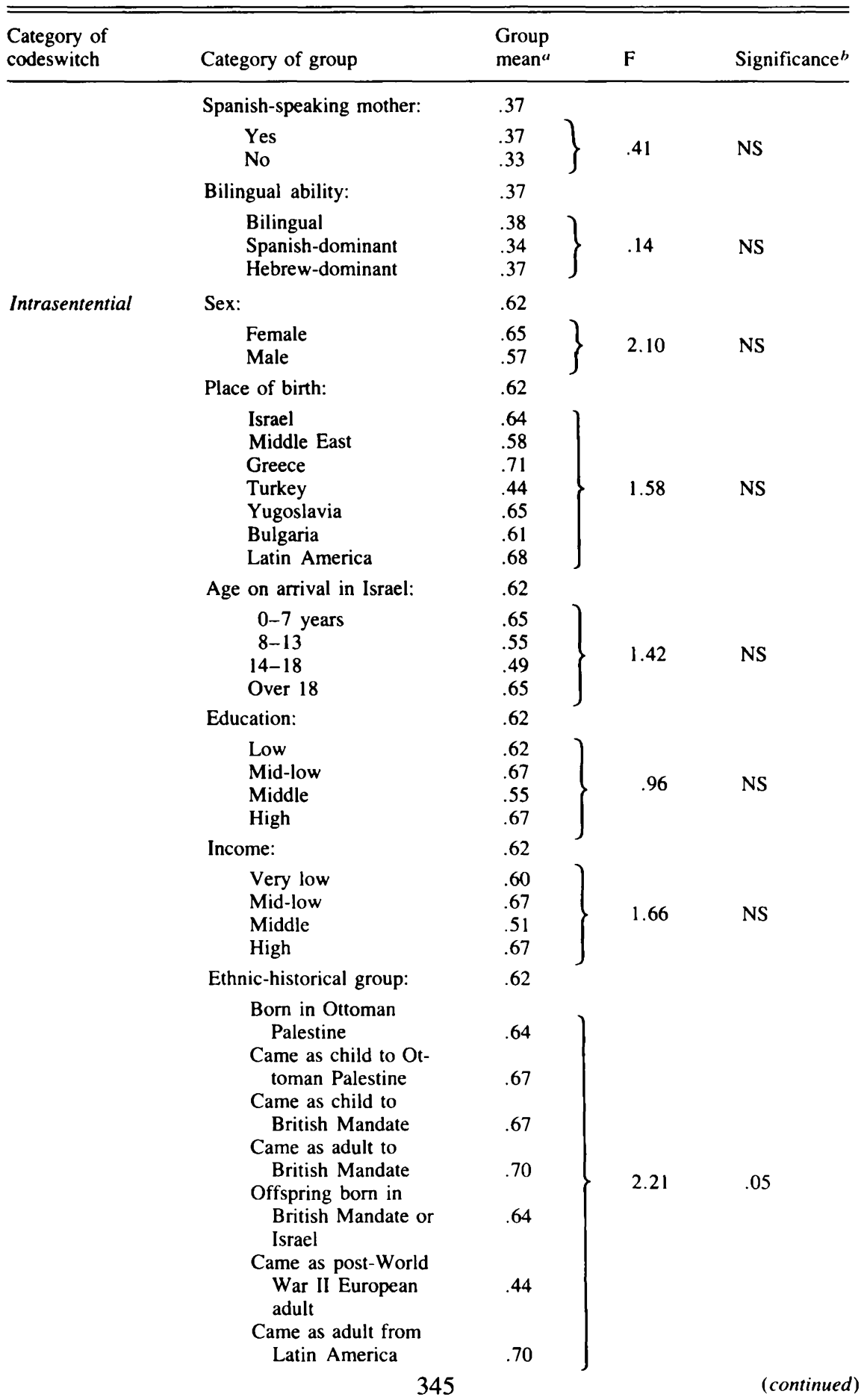


APPENDIX (Continued)

\begin{tabular}{|c|c|c|c|c|}
\hline $\begin{array}{l}\text { Category of } \\
\text { codeswitch }\end{array}$ & Category of group & $\begin{array}{l}\text { Group } \\
\text { mean }^{a}\end{array}$ & $\mathrm{~F}$ & Significance ${ }^{b}$ \\
\hline & $\begin{array}{l}\text { No. of generations in } \\
\text { Israel: }\end{array}$ & .62 & & \\
\hline & $\begin{array}{l}1 \\
2 \\
3 \\
4 \\
5 \text { and greater }\end{array}$ & $\begin{array}{l}.62 \\
.63 \\
.65 \\
.71 \\
.58\end{array}$ & .47 & NS \\
\hline & Spanish-speaking mother: & .62 & & \\
\hline & $\begin{array}{l}\text { Yes } \\
\text { No }\end{array}$ & $\begin{array}{l}.62 \\
.64\end{array}$ & .18 & NS \\
\hline & Bilingual ability: & .62 & & \\
\hline & $\begin{array}{l}\text { Bilingual } \\
\text { Spanish-dominant } \\
\text { Hebrew-dominant }\end{array}$ & $\begin{array}{l}.61 \\
.65 \\
.62\end{array}$ & .23 & NS \\
\hline \multirow{9}{*}{$\begin{array}{l}\text { Intrasentential } \\
\text { large-sized } \\
\text { constituents }\end{array}$} & Sex: & .03 & & \\
\hline & $\begin{array}{l}\text { Female } \\
\text { Male }\end{array}$ & $\begin{array}{l}.01 \\
.04\end{array}$ & 1.58 & NS \\
\hline & Place of birth: & .03 & & \\
\hline & $\begin{array}{l}\text { Israel } \\
\text { Middle East } \\
\text { Greece } \\
\text { Turkey } \\
\text { Yugoslavia } \\
\text { Bulgaria } \\
\text { Latin America }\end{array}$ & $\begin{array}{l}.04 \\
.03 \\
.00 \\
.02 \\
.01 \\
.02 \\
.01\end{array}$ & .26 & NS \\
\hline & $\begin{array}{l}\text { Age on arrival: } \\
0-7 \text { years } \\
8-13 \\
14-18 \\
\text { Over } 18\end{array}$ & $\begin{array}{l}.03 \\
.04 \\
.02 \\
.00 \\
.01\end{array}$ & .46 & NS \\
\hline & Education: & .03 & & \\
\hline & $\begin{array}{l}\text { Low } \\
\text { Mid-low } \\
\text { Middle } \\
\text { High }\end{array}$ & $\begin{array}{l}.02 \\
.00 \\
.06 \\
.01\end{array}$ & 1.04 & NS \\
\hline & Income: & .03 & & \\
\hline & $\begin{array}{l}\text { Very low } \\
\text { Mid-low } \\
\text { Middle } \\
\text { High }\end{array}$ & $\begin{array}{l}.02 \\
.09 \\
.00 \\
.01\end{array}$ & 2.11 & NS \\
\hline
\end{tabular}


APPENDIX (Continued)

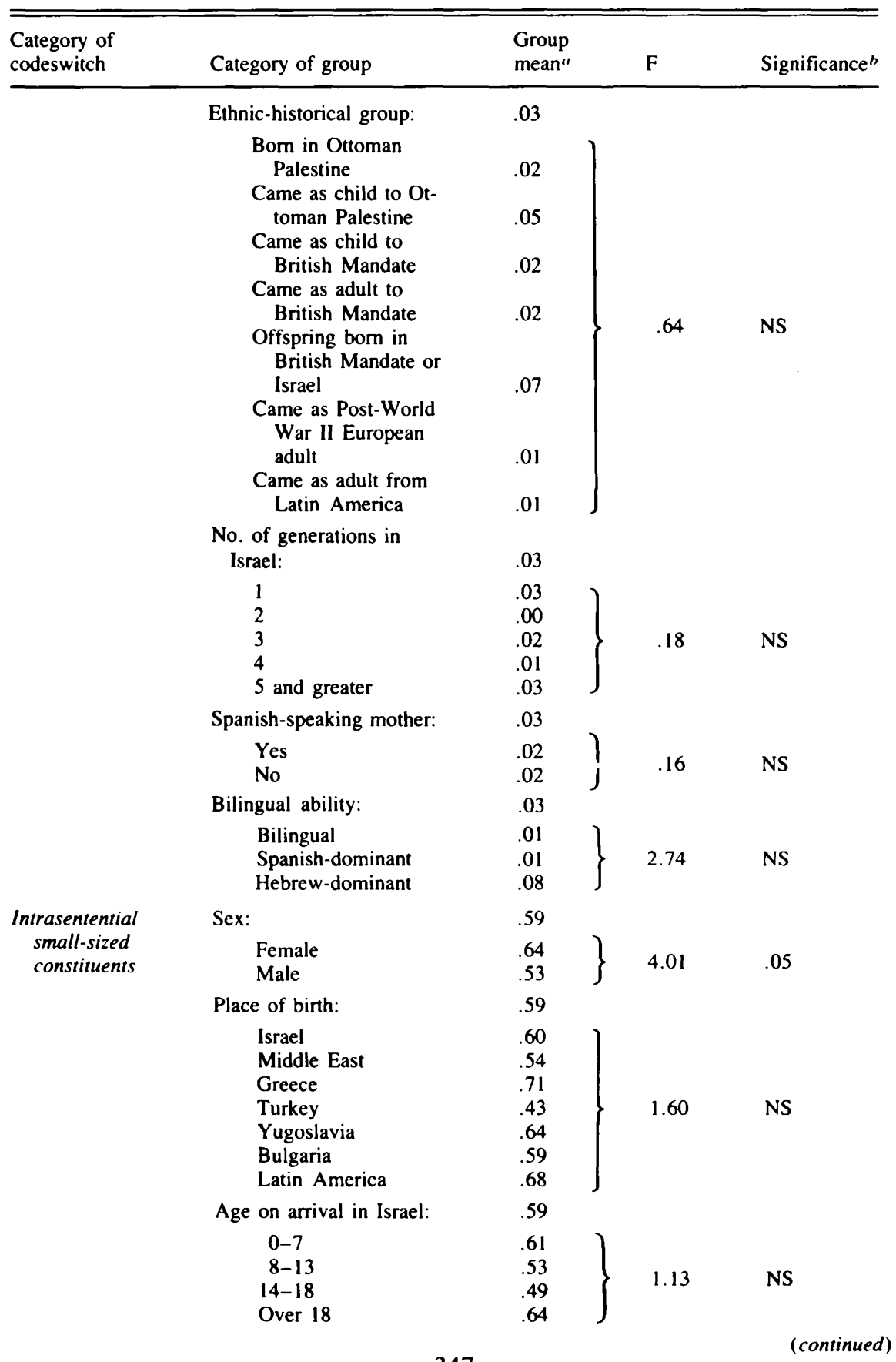


APPENDIX (Continued)

\begin{tabular}{|c|c|c|c|c|}
\hline $\begin{array}{l}\text { Category of } \\
\text { codeswitch }\end{array}$ & Category of group & $\begin{array}{l}\text { Group } \\
\text { mean }\end{array}$ & $\mathbf{F}$ & Significance ${ }^{b}$ \\
\hline & Education: & .59 & \multirow[b]{2}{*}{1.99} & \multirow[b]{2}{*}{ NS } \\
\hline & $\begin{array}{l}\text { Low } \\
\text { Mid-low } \\
\text { Middle } \\
\text { High }\end{array}$ & $\begin{array}{l}.59 \\
.66 \\
.49 \\
.66\end{array}$ & & \\
\hline & Income: & .59 & & \\
\hline & $\begin{array}{l}\text { Very low } \\
\text { Mid-low } \\
\text { Middle } \\
\text { High }\end{array}$ & $\begin{array}{l}.58 \\
.57 \\
.50 \\
.66\end{array}$ & 1.32 & NS \\
\hline & Ethnic-historical group: & .59 & \multirow[b]{2}{*}{2.12} & \multirow[b]{2}{*}{ NS } \\
\hline & $\begin{array}{l}\text { Born in Ottoman } \\
\text { Palestine } \\
\text { Came as child to Ot- } \\
\text { toman Palestine } \\
\text { Came as child to } \\
\text { British Mandate } \\
\text { Came as adult to } \\
\text { British Mandate } \\
\text { Offspring born in } \\
\text { British Mandate or } \\
\text { lsrael } \\
\text { Came as post-World } \\
\text { War II European } \\
\text { adult } \\
\text { Came as adult from } \\
\text { Latin America }\end{array}$ & $\begin{array}{l}.62 \\
.62 \\
.65 \\
.68\end{array}$ & & \\
\hline & $\begin{array}{l}\text { No. of generations in } \\
\text { Israel: }\end{array}$ & .59 & \multirow[b]{2}{*}{.46} & \multirow[b]{2}{*}{ NS } \\
\hline & $\begin{array}{l}1 \\
2 \\
3 \\
4 \\
5 \text { and greater }\end{array}$ & $\begin{array}{l}.59 \\
.63 \\
.64 \\
.70 \\
.56\end{array}$ & & \\
\hline & Spanish-speaking mother: & .59 & \multirow{3}{*}{.37} & \multirow[b]{2}{*}{ NS } \\
\hline & $\begin{array}{l}\text { Yes } \\
\text { No }\end{array}$ & $\begin{array}{l}.59 \\
.63\end{array}$ & & \\
\hline & Bilingual ability: & .59 & & \multirow[b]{2}{*}{ NS } \\
\hline & $\begin{array}{l}\text { Bilingual } \\
\text { Spanish-dominant } \\
\text { Hebrew-dominant }\end{array}$ & $\begin{array}{l}.59 \\
.65 \\
.54\end{array}$ & .77 & \\
\hline
\end{tabular}

"Group means are calculated as the total number of codeswitches of a particular category (e.g., intrasentential) as a percentage of all codeswitches that had occurred.

bSignificance of .05 level or better. 